\title{
Fossil versus contemporary sources of fine elemental and organic carbonaceous particulate matter during the DAURE campaign in Northeast Spain
}

M. C. Minguillón ${ }^{1,2}$, N. Perron ${ }^{1, *}$, X. Querol ${ }^{2}$, S. Szidat ${ }^{3,4}$, S. M. Fahrni ${ }^{1,3,4}$, A. Alastuey ${ }^{2}$, J. L. Jimenez ${ }^{5,6}$, C. Mohr ${ }^{1}$, A. M. Ortega ${ }^{6,7}$, D. A. Day ${ }^{5,6}$, V. A. Lanz ${ }^{1}$, L. Wacker $^{8}$, C. Reche ${ }^{2}$, M. Cusack ${ }^{2}$, F. Amato ${ }^{2}$, G. Kiss ${ }^{9}$, A. Hoffer ${ }^{9}$, S. Decesari ${ }^{10}$, F. Moretti ${ }^{10}$, R. Hillamo ${ }^{11}$, K. Teinilä ${ }^{11}$, R. Seco ${ }^{12, * *}$, J. Peñuelas ${ }^{12}$, A. Metzger ${ }^{13}$, S. Schallhart ${ }^{13}$, M. Müller ${ }^{13}$, A. Hansel ${ }^{13}$, J. F. Burkhart ${ }^{14}$, U. Baltensperger ${ }^{1}$, and A. S. H. Prévôt ${ }^{1}$

${ }^{1}$ Paul Scherrer Institut, Laboratory of Atmospheric Chemistry, 5232 Villigen PSI, Switzerland

${ }^{2}$ Institute of Environmental Assessment and Water Research (IDAEA), CSIC, 08034 Barcelona, Spain

${ }^{3}$ Dept. of Chemistry and Biochemistry, University of Bern, 3012 Berne, Switzerland

${ }^{4}$ Oeschger Centre for Climate Change Research, University of Bern, 3012 Berne, Switzerland

${ }^{5}$ Dept. of Chemistry and Biochemistry, University of Colorado, Boulder, CO, USA

${ }^{6}$ Cooperative Institute for Research in Environmental Sciences (CIRES), USA

${ }^{7}$ Dept. of Atmospheric and Oceanic Science, University of Colorado, Boulder, CO, USA

${ }^{8}$ Laboratory of Ion Beam Physics, ETH Hönggerberg, 8093 Zurich, Switzerland

${ }^{9}$ Air Chemistry Group of the Hungarian Academy of Sciences, University of Pannonia, 8201 Veszprém, Hungary

${ }^{10}$ Institute for Atmospheric Sciences and Climate (ISAC), CNR, Bologna, Italy

${ }^{11}$ Finnish Meteorological Institute, Air Quality Research, 00101 Helsinki, Finland

${ }^{12}$ Unitat d'Ecologia Global CREAF-CEAB-CSIC, Centre de Recerca Ecològica i Aplicacions Forestals (CREAF),

Universitat Autònoma de Barcelona, 08193 Bellaterra, Barcelona, Spain

${ }^{13}$ Institute of Ion Physics and Applied Physics, Innsbruck University, 6020 Innsbruck, Austria

${ }^{14}$ Norwegian Institute for Air Research (NILU), 2027 Kjeller, Norway

*now at: Dept. of Nuclear Physics, University of Lund, 22100 Lund, Sweden

*** now at: Atmospheric Chemistry Division, National Center for Atmospheric Research, Boulder, CO 80301, USA

Received: 26 July 2011 - Published in Atmos. Chem. Phys. Discuss.: 19 August 2011

Revised: 28 October 2011 - Accepted: 16 November 2011 - Published: 6 December 2011

\begin{abstract}
We present results from the international field campaign DAURE (Determination of the sources of atmospheric Aerosols in Urban and Rural Environments in the Western Mediterranean), with the objective of apportioning the sources of fine carbonaceous aerosols. Submicron fine particulate matter $\left(\mathrm{PM}_{1}\right)$ samples were collected during February-March 2009 and July 2009 at an urban background site in Barcelona (BCN) and at a forested regional background site in Montseny (MSY). We present radiocarbon $\left({ }^{14} \mathrm{C}\right)$ analysis for elemental and organic carbon (EC and $\mathrm{OC}$ ) and source apportionment for these data. We combine the results with those from component analysis of aerosol mass spectrometer (AMS) measurements, and
\end{abstract}

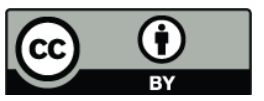

Correspondence to: M. C. Minguillón (mariacruz.minguillon@idaea.csic.es) compare to levoglucosan-based estimates of biomass burning $\mathrm{OC}$, source apportionment of filter data with inorganic composition + EC + OC, submicron bulk potassium $(\mathrm{K})$ concentrations, and gaseous acetonitrile concentrations.

At $\mathrm{BCN}, 87 \%$ and $91 \%$ of the EC on average, in winter and summer, respectively, had a fossil origin, whereas at MSY these fractions were $66 \%$ and $79 \%$. The contribution of fossil sources to organic carbon (OC) at BCN was $40 \%$ and $48 \%$, in winter and summer, respectively, and $31 \%$ and $25 \%$ at MSY. The combination of results obtained using the ${ }^{14} \mathrm{C}$ technique, AMS data, and the correlations between fossil OC and fossil EC imply that the fossil OC at Barcelona is $\sim 47 \%$ primary whereas at MSY the fossil OC is mainly secondary $(\sim 85 \%)$. Day-to-day variation in total carbonaceous aerosol loading and the relative contributions of different sources predominantly depended on the meteorological transport conditions. The estimated

Published by Copernicus Publications on behalf of the European Geosciences Union. 
biogenic secondary OC at MSY only increased by $~ 40 \%$ compared to the order-of-magnitude increase observed for biogenic volatile organic compounds (VOCs) between winter and summer, which highlights the uncertainties in the estimation of that component. Biomass burning contributions estimated using the ${ }^{14} \mathrm{C}$ technique ranged from similar to slightly higher than when estimated using other techniques, and the different estimations were highly or moderately correlated. Differences can be explained by the contribution of secondary organic matter (not included in the primary biomass burning source estimates), and/or by an overestimation of the biomass burning OC contribution by the ${ }^{14} \mathrm{C}$ technique if the estimated biomass burning EC/OC ratio used for the calculations is too high for this region. Acetonitrile concentrations correlate well with the biomass burning EC determined by ${ }^{14} \mathrm{C}$. $\mathrm{K}$ is a noisy tracer for biomass burning.

\section{Introduction}

Ambient aerosols have adverse effects on human health (e.g., Nel, 2005; Pope and Dockery, 2006; Krzyzanowski and Cohen, 2008). They also affect climate through their direct (absorption and scattering) and indirect (cloud interactions) effects on the Earth's radiative balance (Forster et al., 2007), ecosystems and crops through their deposition of acids, toxics, and nutrients (e.g., Matson et al. 2002; Grantz et al., 2003), and regional visibility (e.g., Watson, 2002).

Submicron particulate matter $\left(\mathrm{PM}_{1}\right.$, particles with an aerodynamic diameter $<1 \mu \mathrm{m}$ ) contains substantial fractions of carbonaceous aerosol (Murphy et al., 2006; Jimenez et al., 2009). Carbonaceous aerosol comprises a wide variety of organic compounds, collectively referred to as organic matter (OM), elemental carbon (EC), and carbonate mineral dust, the latter typically being negligible in submicron aerosol since it is mainly present in the coarse fraction (Sillanpää et al., 2005).

Carbonaceous aerosols are responsible for some of the adverse effects on human health produced by particles ( $\mathrm{Li}$ et al., 2003; Mauderly and Chow, 2008). Some organic compounds are respiratory irritants (such as carbonyls and acids), carcinogens (such as polycyclic aromatic hydrocarbons (PAHs)), and toxins (Mauderly and Chow, 2008). EC induces respiratory and cardiovascular problems (Highwood and Kinnersley, 2006; and references therein) and may adsorb toxic or carcinogenic organic species which may then be absorbed into lung tissue (Gerde et al., 2001).

An accurate knowledge of the sources of EC and OM is necessary to design strategies aimed at mitigating the effects of aerosols. Known sources of carbonaceous aerosols are biomass, biofuel, and waste burning, residential heating, cooking, fossil-fuel combustion (including road traffic emissions), and biogenic emissions (Hildemann et al.,
1994; Schauer et al., 1996). Biogenic emissions contribute to primary organic aerosol (POA) and secondary organic aerosol (SOA), which is formed from biogenic gases such as isoprene and monoterpenes. Biogenic POA is dominantly in the supermicron mode while biogenic SOA is concentrated in the submicron mode (Pöschl et al., 2010).

Radiocarbon $\left({ }^{14} \mathrm{C}\right)$ analysis is a powerful tool used to help apportion the sources of carbonaceous aerosols (Currie, 2000; Szidat, 2009), due to its ability to differentiate between aerosol carbon arising from contemporary and fossil sources. In contemporary carbonaceous sources ${ }^{14} \mathrm{C}$ is found at levels similar to those in $\mathrm{CO}_{2}$ in the present-day atmosphere, or higher for sources of "stored carbon" such as wood burning. In contrast, in fossil sources, whose age greatly exceeds the half-life of ${ }^{14} \mathrm{C}$ (5730 years), ${ }^{14} \mathrm{C}$ has completely decayed. The radiocarbon content of a carbonaceous sample is expressed as the "fraction of modern carbon" (fM), and is referenced to the ratio ${ }^{14} \mathrm{C} /{ }^{12} \mathrm{C}$ in atmospheric $\mathrm{CO}_{2}$ in the year 1950 (Stuiver and Polach, 1977):

$$
\mathrm{fM}=\frac{\left({ }^{14} \mathrm{C} /{ }^{12} \mathrm{C}\right)_{\text {sample }}}{\left({ }^{14} \mathrm{C} /{ }^{12} \mathrm{C}\right)_{\mathrm{AD} 1950}}
$$

Values of $\mathrm{fM}$ range from zero for fossil sources to more than one for contemporary sources. The $\mathrm{fM}$ for contemporary sources exceeds unity due to the atmospheric nuclear weapon tests in the 1950s and 1960s that significantly increased the radiocarbon content of the atmosphere (Levin et al., 2010). Here we will use the term "modern carbon" only to refer to measurements relative to the 1950 standard, and the terms "contemporary" or "non-fossil," and "fossil" carbon to refer to quantities after correction of the excess bomb radiocarbon. Since EC and OC may have different sources, source apportionment of EC and OC separately (as opposed to only total carbon, TC) provides additional valuable information.

Several previous studies have reported contemporary and fossil fractions of carbonaceous aerosols in urban and rural European areas in $\mathrm{PM}_{1}, \mathrm{PM}_{2.5}, \mathrm{PM}_{10}$ and Total Suspended Particles (TSP, Table 1). In urban areas, EC was found to be $84-97 \%$ fossil in summer or spring and $30-91 \%$ fossil in winter or autumn, whereas the OC fraction was $28-47 \%$ fossil in summer or spring and $32-45 \%$ fossil in winter or autumn. In rural areas, the ranges are very wide, EC was $27-97 \%$ fossil and OC was 9-58\% fossil in any season. In general, the fossil contribution in rural areas was usually lower than the equivalent urban area for both EC and OC. For nearly all sites, the fossil contribution was larger in EC than in OC, and it was more important in summer than in winter for EC, whereas for OC the difference between summer and winter was variable, probably due to the different influences of biogenic emissions depending on the site. Other studies in Asian areas such as the Maldives, West India and Japan reported lower fossil contributions to black carbon (BC, 31$58 \%$, Table 1) and lower or similar fossil contributions to OC (6-38\%, Table 1$)$. This is probably a consequence of the more common use of biomass burning for cooking in Asia 
with respect to Europe. Finally, in Mexico City the fossil contribution to OC was higher than that found in European or Asian areas (49-62\%), even during high-fire periods (Table 1).

The present study is part of the international field campaign DAURE (Determination of the sources of atmospheric Aerosols in Urban and Rural Environments in the Western Mediterranean) (Pandolfi et al., 2011b; Jorba et al., 2011; http://tinyurl.com/daure09). The objective of DAURE is to study the causes of regional scale aerosol pollution episodes during winter and summer in the Western Mediterranean Basin (WMB). The WMB presents unique atmospheric dynamics regulated by complex climatic and orographic effects which control the concentration, composition and transport of PM (Millán et al., 1997). In general, in summertime, local circulation dominates the atmospheric dynamics over the WMB, enhancing the regional accumulation of pollutants and the stratification of polluted air masses (Millán et al., 1997). In winter, the inflow of clean Atlantic air masses into the WMB favors the reduction of pollution levels. However, during some periods characterized by winter anticyclonic conditions, pollution from the coast and valleys is accumulated due to thermal inversions persisting for a few days. After several days under anticyclonic conditions local upslope breezes can be driven by solar radiation pushing polluted air masses from the valley towards rural mountainous areas, thereby markedly increasing the PM levels in the rural mountainous areas (Pérez et al., 2008a; Pey et al., 2009, 2010). Specific scenarios during the campaign are described later. Together with these transport scenarios, the large emissions from the densely populated and industrialized areas, sporadic forest fires, and large shipping emissions give rise to a complex phenomenology for aerosol formation and transformation.

In this context, the present work focuses on characterizing the sources of fine carbonaceous aerosols, by using the ${ }^{14} \mathrm{C}$ method and comparing it to results from other apportionment methods such as receptor modeling of filter PM measurements (inorganic composition, EC and OC concentrations) and Aerosol Mass Spectrometer (AMS) data, and biomass burning source estimates from levoglucosan measurements. This is the first time that these techniques have been applied simultaneously in the Mediterranean region.

\section{Methodology}

\subsection{Sampling}

Two sampling sites were selected: Barcelona $(\mathrm{BCN})$, an urban background site $\left(41^{\circ} 23^{\prime} 24^{\prime \prime} \mathrm{N} 02^{\circ} 06^{\prime} 58^{\prime \prime} \mathrm{E}, 80 \mathrm{~m}\right.$ a.s.l.), and Montseny (MSY), a forested regional background site $50 \mathrm{~km}$ away from Barcelona $\left(41^{\circ} 46^{\prime} 46^{\prime \prime} \mathrm{N} 02^{\circ} 21^{\prime} 29^{\prime \prime} \mathrm{E}\right.$, $720 \mathrm{~m}$ a.s.1.), which is part of the European Supersite for Atmospheric Aerosol Research (EUSAAR) network (http: //www.eusaar.net). Sampling was carried out during two different seasons: February-March 2009, called the DAURE winter campaign (DAURE-W), and July 2009, called the DAURE summer campaign (DAURE-S).

Submicron fine particulate matter $\left(\mathrm{PM}_{1}\right)$ samples were collected on quartz fiber filters (Munktell in DAURE-W and Pallflex 2500QAT-UP in DAURE-S) using DIGITEL (DH77 in DAURE-W and DHA-80 in DAURE-S) high volume $\left(30 \mathrm{~m}^{3} \mathrm{~h}^{-1}\right)$ samplers with a $\mathrm{PM}_{1}$ impactor inlet. Sampling periods were $48 \mathrm{~h}$ in winter and $24 \mathrm{~h}$ in summer. We attempted to minimize artefacts after sampling by keeping the samples at $-20^{\circ} \mathrm{C}$ after sampling and prior to analysis. With the instrumentation deployed during this study it is not possible to estimate the possible sampling artefacts, which are both positive (capture of semivolatile gases in the filter) and negative (evaporation of semivolatile particle species). For quartz filters one might rather expect positive artefacts. Those are however not expected to be very large at high OC loadings. Here we assume that the possible sampling artefacts (evaporated or condensed material) have the same fM as that of the original particle material, i.e. we assumed that the artefacts do not affect the fM results. From all samples collected, 7 samples from each site were selected from DAURE$\mathrm{W}$ and 6 from DAURE-S. These 26 samples were used for ${ }^{14} \mathrm{C}$ analysis. Selection of the samples was based upon simultaneous availability of samples at both sites, preliminary results (at the time of sample selection) from AMS measurements (only winter), and the EC and OC concentrations, to investigate different atmospheric scenarios. Two blank filters were processed and analyzed following the same methodology as the collected samples and concentrations were subtracted to those found for the samples in order to calculate the ambient concentrations. All the concentrations are reported under ambient temperature and pressure conditions.

$\mathrm{NO}_{\mathrm{x}}$ concentrations were measured at both sites by conventional gas phase air pollution monitors (Thermo Scientific, Model 42i) by the Department of the Environment of the Generalitat de Catalunya.

\subsection{Analyses of EC and $\mathrm{OC}$ and intercomparison}

$\mathrm{EC}$ and $\mathrm{OC}$ concentrations were determined using the 26 samples collected for ${ }^{14} \mathrm{C}$ analysis plus the two blank filters by a thermo-optical method with a Sunset OC/EC Field Analyzer (RT 3080, Sunset Laboratory Inc., USA), which was used off-line (Bae et al., 2004). The EUSAAR2 protocol (Cavalli et al., 2010) was used. These results will be referred to as Sunset1. Blank OC concentrations were 4-23\% (11\% on average) of the sample concentrations and blank EC concentrations were below $0.1 \%$ of the sample concentrations. These Sunset 1 concentrations of EC and OC were compared to other measurements:

- EC and OC concentrations measured by a different Sunset OC/EC analyzer (laboratory model) using the 
EUSAAR2 protocol. In DAURE-S, the analysis was carried out on the same filters used for Sunset1. In DAURE-W, it was carried out on $\mathrm{PM}_{1} 12 \mathrm{~h}$ samples collected on quartz fiber filters (Munktell) using high volume $\left(30 \mathrm{~m}^{3} \mathrm{~h}^{-1}\right)$ samplers (DIGITEL DHA-80). These results will be referred to as Sunset2.

- EC and OC concentrations measured by gauge pressure in a calibrated volume during the $\mathrm{EC}$ and $\mathrm{OC}$ separation and collection for subsequent ${ }^{14} \mathrm{C}$ analysis (Szidat et al., 2004b, see description in Sect. 2.3).

- OC concentrations calculated from OM concentrations measured by AMS (method details in Aiken et al., 2008) in DAURE-W. The calculations were done using OM:OC ratios determined by high-resolution analysis of the AMS mass spectra. On average, the OM:OC ratio was 1.6 at $\mathrm{BCN}$ and 2.0 at MSY. The specific OM:OC ratios for different $\mathrm{OA}$ components were very similar: 1.29 at MSY and 1.21 at BCN for hydrocarbon-like organic aerosol (HOA); 1.52 at MSY and 1.53 at BCN for biomass burning organic aerosol (BBOA); 2.04 at MSY for oxygenated organic aerosol (OOA) and 1.61 (semivolatile OOA, SV-OOA) and 2.14 (low-volatility OOA, LV-OOA) at BCN.

- EC concentrations measured by the Sunset instrument during the $\mathrm{CO}_{2}$ collection for ${ }^{14} \mathrm{C}$ measurements corresponding to the third stage of the thermal program, as explained in Sect. 2.3.

- Black carbon concentrations measured by a Multi Angle Absorption Photometer (MAAP) with a $\mathrm{PM}_{10}$ inlet. Absorption coefficients used were $10.4 \mathrm{~m}^{2} \mathrm{~g}^{-1}$ and $9.2 \mathrm{~m}^{2} \mathrm{~g}^{-1}$ for MSY and BCN, respectively (Pandolfi et al., 2011a; Reche et al., 2011)

The results are generally consistent within the uncertainties in the different measurements, especially in terms of trends, while some differences in the absolute magnitudes are apparent (Fig. S1). At BCN the bulk OC from the AMS was substantially higher than that measured by the rest of the instruments (Fig. S1), which we attribute to higher than usual uncertainties in the calibration of that instrument due to custom modifications of the ionization region. Therefore absolute concentrations of OC from different sources calculated based on these different measurements should be compared with caution, while fractional contributions should be more directly comparable. In the following, the EC and OC concentrations used are those measured by the Sunset1 instrument (using the samples collected for ${ }^{14} \mathrm{C}$ analysis), unless otherwise specified. Associated error bars of EC and OC measured by Sunset 1 lower than $20 \%$ of the concentration were increased to $20 \%$ to better reflect the uncertainty in the measurements, shown by the differences among different methods (Fig. S1) and based on round-robin tests within the EUSAAR project (EUSAAR Deliverable NA2/D10 new report).

\subsection{Separation of carbonaceous fractions and ${ }^{14} \mathrm{C}$ measurements}

The method for the separation of carbonaceous particle fractions is based on the different chemical and thermal behavior of OC and EC in the presence of oxygen gas as shown by Lavanchy et al. (1999). This separation is complicated by the fact that there is not a clear boundary between OC and EC, since OC compounds are less volatile and more optically absorptive with increasing molecular weight and functionality; and the least refractory part of EC may show similar chemical and physical behavior as high molecular weight OC. The separation method has been described in detail elsewhere (Szidat et al., 2004a). Briefly, OC is oxidized on a filter at $340^{\circ} \mathrm{C}$ in a stream of pure oxygen for $10 \mathrm{~min}$. Evolved $\mathrm{CO}_{2}$ is trapped cryogenically, quantified manometrically in a calibrated volume, and sealed in ampoules for ${ }^{14} \mathrm{C}$ measurement. Using this method, part of the OC pyrolyses on the filter to form refractory material (an artifact known as "charring") and is therefore not collected. This approach assumes identical $\mathrm{fM}$ of the measured and the neglected fraction, which was shown to be correct for "Urban Dust" in NIST reference material SRM 1649a (Szidat et al., 2004b). The uncertainty due to this loss of OC can be estimated as 0.03 (absolute value) of $\mathrm{fM}_{\mathrm{OC}}$. This is based on an estimation of $\sim 20 \%$ of $\mathrm{OC}$ losses and $\mathrm{fM}_{\mathrm{EC}}$ measurements with and without water extraction prior to $\mathrm{CO}_{2}$ collection (Szidat et al., 2004a). Therefore, the uncertainties reported here take into account the ${ }^{14} \mathrm{C}$ measurement uncertainty (see explanation in the end of this section) and this charring uncertainty of 0.03 .

Isolation of EC for accurate ${ }^{14} \mathrm{C}$ determination targets a complete removal of OC prior to EC collection with the best possible EC recovery. Since the modern fractions of EC and OC can differ significantly (e.g. Szidat et al., 2004a, 2009), incomplete OC removal could bias the result of the $\mathrm{fM}$ in the $\mathrm{EC}$ fraction $\left(\mathrm{fM}_{\mathrm{EC}}\right)$. For this study, a new method for EC collection (modified from that described by Szidat et al., 2004a) developed in our laboratory was used. A detailed description can be found in the Supplementary Material (Sect. S3 and S4, Figs. S2, S3 and S4). Briefly, water extraction is carried out prior to separation and EC collection, so that water soluble organic and inorganic compounds are removed (Szidat et al., 2004a, 2009). This minimizes a possible positive artifact due to the aforementioned OC charring during the first thermal steps (to remove OC). This charring would produce additional EC-like material, which would be combusted and collected during the EC step at $650^{\circ} \mathrm{C}$. This new method includes the coupling of a Sunset instrument to the cryo-trap system (as opposed to an oven with a fixed temperature with the Szidat et al. (2004a) method), so that the thermal cycles are defined accurately (see Supp. Material). The combustion process is carried out under pure oxygen. The thermal 
Table 1. Compilation of literature values of $\%$ fossil carbon in different fractions and sites and results from the present study.

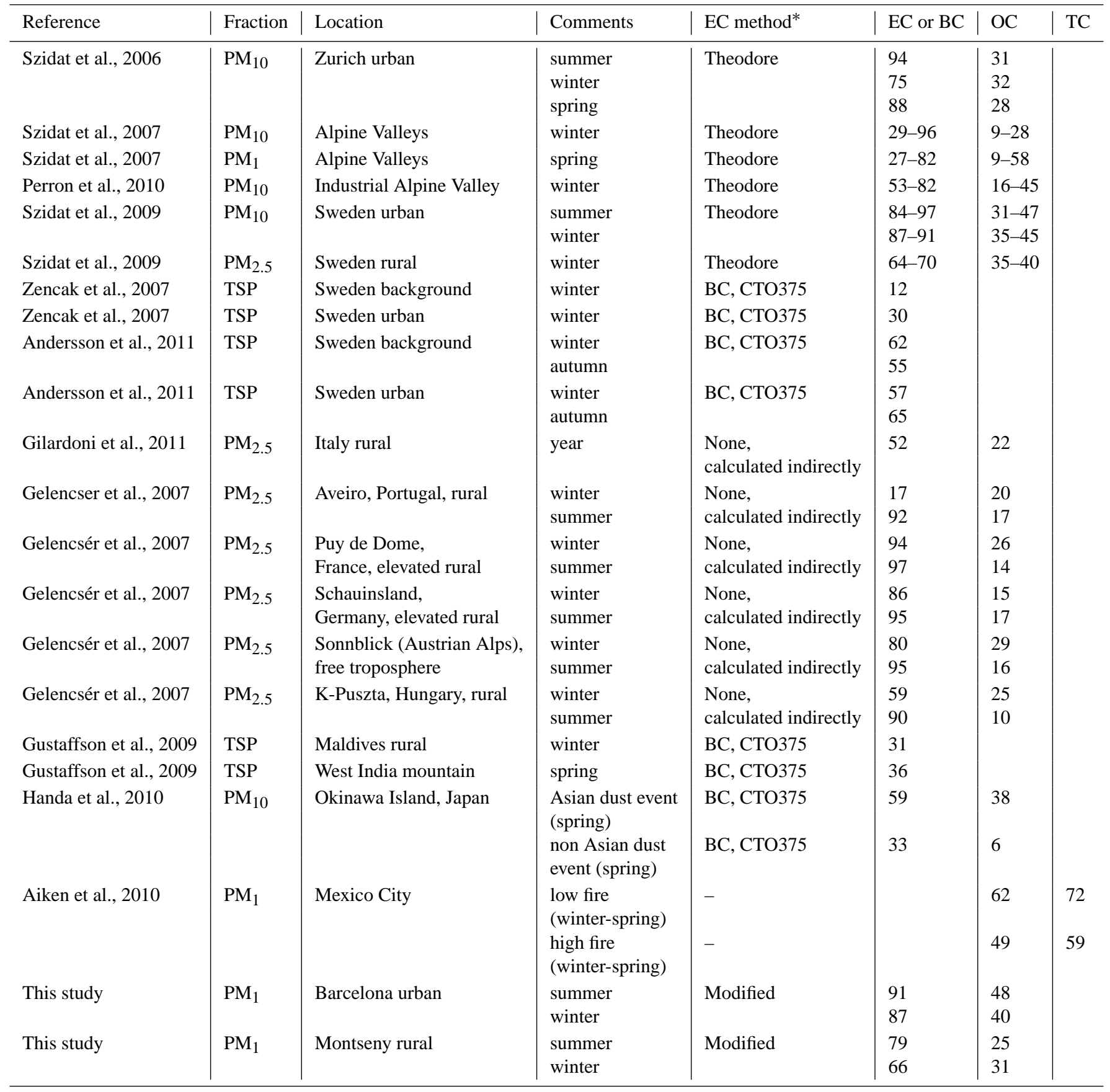

* Method for isolating the elemental carbon: Theodore method (Szidat et al., 2004a and b) has yields of 60-80\% of the total EC determined by thermo-optical methods; BC, CTO375 method (Gustafsson et al., 1997 and 2001) recovers a fraction called BC, having yields of around $10 \%$ of the total EC determined by thermo-optical methods. 
program is set to minimize a possible negative artifact resulting from removal of the least refractory part of $\mathrm{EC}$ in the first thermal steps prior to EC collection. This method allows us to collect more EC compared to the $60-80 \%$ recovery obtained with the Szidat et al. (2004a) method and the $\mathrm{fM}$ obtained are thus more representative of the complete EC fraction. The EC recovery was on average $90 \%$ and $86 \%$ for DAURE-W and DAURE-S, respectively. A rough estimate of the uncertainty generated by the $10-14 \%$ EC loss would be an underestimation of $\mathrm{fM}_{\mathrm{EC}}$ by $0.02-0.04$ (Perron, 2010 ), which results in $<5 \%$ (absolute percent) possible underestimation of the biomass burning EC contribution. This possible bias in the $\mathrm{fM}_{\mathrm{EC}}$ should be taken only as an estimate and therefore it is discussed here but not included in the calculations.

The samples from the MSY summer campaign had very low EC concentrations. Therefore six individual combustions of each of the samples were carried out and the $\mathrm{CO}_{2}$ collected was combined for a single subsequent ${ }^{14} \mathrm{C}$ analysis.

After the separation and collection of $\mathrm{OC}$ and $\mathrm{EC}$ as $\mathrm{CO}_{2}$ samples, ${ }^{14} \mathrm{C}$ analyses were performed at ETH Zurich with the Accelerator Mass Spectrometer MICADAS using a gas ion source (Ruff et al., 2007, 2010). The fM for each sample was then blank subtracted using an average of the fM of the two blank filters analyzed, and taking into account the amount of $\mathrm{C}$ analyzed in each sample and in the blank filters. $\mathrm{fM}$ measurement uncertainty was calculated based on the Accelerator Mass Spectrometer sample and blank uncertainties and the amounts of $\mathrm{C}$ analyzed. On average, $\mathrm{fM}_{\mathrm{OC}}$ measurement uncertainty was $2.4 \%$ and $4 \%$ of the corresponding $\mathrm{fM}_{\mathrm{OC}}$ for winter and summer, respectively; and $\mathrm{fM}_{\mathrm{EC}}$ measurement uncertainty was $6 \%$ and $28 \%$ of the corresponding $\mathrm{fM}_{\mathrm{EC}}$ for winter and summer, respectively.

\subsection{Source apportionment of EC and $\mathrm{OC}$ using ${ }^{14} \mathrm{C}$ data}

Source apportionment of EC and OC is based on their concentrations, ${ }^{14} \mathrm{C}$ isotopic ratios of these two components, and the expected $\mathrm{fM}$ of the corresponding sources. The reference values for the different sources used in the present study are $\mathrm{fM}_{\mathrm{f}}=0$ (for fossil sources); $\mathrm{fM}_{\mathrm{bb}}=1.083$ (for biomass burning), corresponding to emissions from burning of 25year-old trees harvested in 2007-2008 as determined with a tree-growth model (Mohn et al., 2008); and $\mathrm{fM}_{\text {bio }}=1.045$ (for biogenic sources), corresponding to 2008-2009 from the long-term series of atmospheric ${ }^{14} \mathrm{CO}_{2}$ measurements at Jungfraujoch research station (Levin et al., 2010). In the case of $\mathrm{EC}$, the $\mathrm{fM}$ of non-fossil sources $\left(\mathrm{fM}_{\mathrm{nf}}\right)$ equals $\mathrm{fM}_{\mathrm{bb}}$ given that biomass burning is the only source of non-fossil EC. In the case of $\mathrm{OC}, \mathrm{fM}_{\mathrm{nf}}$ is assumed to be the average of $\mathrm{fM}_{\mathrm{bb}}$ and $\mathrm{fM}_{\mathrm{bio}}$, given that the fractions from biomass burning and from biogenic sources are not known a priori, and both sources are thought to play a role in this region. An iterative procedure could be used to refine the initial estimates. It would consist of calculating $\mathrm{fM}_{\mathrm{nf}}$ based on the fractions of biogenic and biomass burning contributions derived from the analysis, and using $\mathrm{fM}_{\mathrm{nf}}$ to the initial calculations, recalculating the fractions of biogenic and biomass burning contributions, and with those recalculate $\mathrm{fM}_{\mathrm{nf}}$, and keep doing so until the recalculated $\mathrm{fM}_{\mathrm{nf}}$ shows a very small change with respect to the previous iteration. However the subsequent differences in the results are small, especially compared to the measurement and method uncertainties, and such a procedure is not used here.

$\mathrm{EC}$ is apportioned into $\mathrm{EC}_{\mathrm{f}}$ and $\mathrm{EC}_{\mathrm{nf}}$, the former attributed to combustion of fossil fuel and the latter attributed to biomass burning $\left(\mathrm{EC}_{\mathrm{bb}}\right) . \mathrm{EC}_{\mathrm{f}}$ can be mainly attributed to road traffic according to previous studies that found that EC in Barcelona is mainly related to road traffic emissions (Pérez et al., 2010). Residential heating as a source of $\mathrm{EC}_{\mathrm{f}}$ is not expected to be very high in the study area due to moderate average temperatures during DAURE-W $\left(13.3 \pm 2.8^{\circ} \mathrm{C}\right.$ in Barcelona and $9.5 \pm 4.0^{\circ} \mathrm{C}$ in Montseny; Pandolfi et al., $2011 \mathrm{~b}$ ), and due to the fact that only $9 \%$ of the residential heating in Barcelona uses solid or liquid fossil fuel, the rest uses natural gas (62\%), electricity (28\%), wood $(0.4 \%)$ and other minor systems $(0.2 \%)$ (INE, 2001). Other sources such as shipping may also make a contribution to $\mathrm{EC}_{\mathrm{f}}$ in Barcelona, although their contribution to PM was found to be relatively low (approximately $20 \%$ of the contribution of vehicular exhaust emissions; Amato et al., 2009).

$\mathrm{OC}$ is separated into $\mathrm{OC}_{\mathrm{f}}$ and $\mathrm{OC}_{\mathrm{nf}}$. $\mathrm{OC}_{\mathrm{f}}$ is attributed to $\mathrm{POA}$ and SOA from fossil fuel combustion. As per $\mathrm{EC}_{\mathrm{f}}$, the contribution of residential heating to $\mathrm{OC}_{\mathrm{f}}$ is expected to be low. As discussed before, $\mathrm{OC}_{\mathrm{nf}}$ may have different origins, such as biomass burning POA and SOA, as well as biogenic SOA. However, some other sources such as cooking, biofuel combustion, brake lining dust, natural rubber in tire dust, and others may account for a substantial fraction of the total contemporary carbon, especially in urban areas (Hildemann et al., 1994). In particular several recent studies report a high fraction of cooking aerosol in urban areas (Zheng et al., 2007; Allan et al., 2010; Huang et al., 2010; Sun et al., 2011). We first present results as $\mathrm{OC}_{\mathrm{nf}}$, without differentiating between biomass burning $\mathrm{OC}\left(\mathrm{OC}_{\mathrm{bb}}\right)$, biogenic $\mathrm{OC}\left(\mathrm{OC}_{\mathrm{bio}}\right)$, and other $\mathrm{OC}_{\mathrm{nf}}$ sources.

In a second step, which allows for comparison with results from other methods, the contribution of biomass burning to $\mathrm{OC}$ is estimated based on an assumed ratio for EC/OC in biomass burning emissions $(\mathrm{EC} / \mathrm{OC})_{\mathrm{bbe}}$, together with the $\mathrm{EC}_{\mathrm{bb}}$ determined by ${ }^{14} \mathrm{C}$ :

$\mathrm{OC}_{\mathrm{bb}}=\frac{\mathrm{EC}_{\mathrm{bb}}}{(\mathrm{EC} / \mathrm{OC})_{\mathrm{bbe}}}$

Nevertheless, the wide range of $(\mathrm{EC} / \mathrm{OC})_{\mathrm{bbe}}$ ratios found in literature (Table S1) leads to high uncertainties in the estimation of $\mathrm{OC}_{\mathrm{bb}}$. The $(\mathrm{EC} / \mathrm{OC})_{\mathrm{bbe}}$ ratio depends on many factors, such as the biofuel type and the combustion method 
used. For calculations here, an average $(\mathrm{EC} / \mathrm{OC})_{\text {bbe }}$ ratio of 0.3 was used, based upon the reported values for common biofuel species in the Mediterranean, with similar combustion methods to those used in Spain (Fine et al., 2004; Gonçalves et al., 2010), and agricultural fires (Chow et al., 2010). SOA formation from biomass burning emissions is quite variable, and a recent summary of seven field studies reports that the net addition of OA mass due to SOA formation averages to $25 \%$ of the POA (Cubison et al., 2011). Therefore SOA formation from biomass burning emissions may lead to $\mathrm{a} \sim 20 \%$ underestimation of the $\mathrm{OC}_{\mathrm{bb}}$ on average.

\subsection{Other source apportionment methods and biomass burning tracers}

Results from three other methods are used here for comparison with the ${ }^{14} \mathrm{C}$-based method for DAURE-W. First, measurements of levoglucosan, an organic tracer of biomass burning (Simoneit et al., 1999) are used. Levoglucosan was determined using the same filters used for ${ }^{14} \mathrm{C}$ analyses $\left(\mathrm{PM}_{1}\right.$ $48 \mathrm{~h}$ samples) by two methods: gas chromatography-mass spectrometry (Agilent 6890N gas chromatograph coupled to a mass spectrometer Agilent $5973 \mathrm{~N}$ ) by the Hungarian Academy of Sciences (lev-HAS), and by proton nuclear magnetic resonance (HNMR, Tagliavini et al., 2006) by the Institute of Atmospheric Sciences and Climate of the Italian National Research Council (lev-ISAC). There are two additional data sets of levoglucosan concentrations (Supp. Material Sect. S5 and Fig. S5) measured by different laboratories, but in this work we used the average of the concentrations of lev-HAS and lev-ISAC as they are consistent with each other, and for maximum overlap with the ${ }^{14} \mathrm{C}$ dataset.

The contribution of primary OC from biomass burning can be estimated from levoglucosan concentrations together with the levoglucosan/OC ratio in biomass burning emissions (lev/OC) bbe:

$\mathrm{OC}_{\mathrm{bb}}=\frac{\mathrm{lev}}{(\mathrm{lev} / \mathrm{OC})_{\mathrm{bbe}}}$

However, the variability of (lev/OC) bbe ratio in the literature is large (Table S1), and the data available for Europe, compared to the US, is scarce (Szidat et al., 2009 and references therein), which results in substantial uncertainty for the results from this method. It is also known that levoglucosan can be oxidized photochemically in the atmosphere (Hennigan et al., 2010; Cubison et al., 2011) and that it can evaporate due to its semi-volatile character (Oja and Suuberg, 1999). Thus estimates from this method using ratios measured for concentrated primary emissions should be considered lower limits. An average (lev/OC) bbe ratio of 0.12 was used (Fine et al., 2004; Schmidl et al., 2008; Sullivan et al., 2008; Szidat et al., 2009; Gonçalves et al., 2010; Saarnio et al., 2010). Nevertheless, given the wide range of ratios reported in the literature, uncertainties were calculated to cover the ratios ranging from 0.07 to 0.17 .

A second method used here for the estimation of OM sources, including $\mathrm{OM}_{\mathrm{bb}}$, is based on factor analysis of AMS measurements. Two high-resolution AMSs were deployed at the BCN and MSY sites (Mohr et al., 2011; Pandolfi et al., 2011b). The AMS instruments, data processing, and analysis techniques have been described in detail elsewhere (DeCarlo et al., 2006; Canagaratna et al., 2007). Positive Matrix Factorization (PMF) of the organic mass spectral data matrix provides information on different sources/components of the OA (Lanz et al., 2007; Ulbrich et al., 2009), such as hydrocarbon-like organic aerosol (HOA), used as a surrogate for urban combustion $\mathrm{POA}, \mathrm{BBOA}$ as a surrogate for POA from biomass burning, and oxygenated OA (OOA) as a surrogate for total SOA. As discussed above, biomass burning emissions can give rise to SOA from organic gases and also from semi-volatile species from the evaporation of the POA (DeCarlo et al., 2010; Cubison et al., 2011). The SOA formed from biomass burning emissions produces similar mass spectra to SOA from other sources (Jimenez et al., 2009) and thus it is lumped together in the oxygenated OA (OOA) factor. The details of the PMF methods and results for BCN can be found in Mohr et al. (2011). For MSY, PMF was performed on the organic $m / z$ vs. time matrix using the PMF2.exe program and analyzed with the PMF Evaluation Tool (PET, http://tinyurl.com/PMF-guide) according to the procedures described on Ulbrich et al. (2009). 771 resolvable ions were fitted in the high-resolution analysis software, PIKA, for $m / z$ 10-206, and were used in the PMF analysis. An 8-factor solution (FPEAK=0) was used since this was the lowest number of factors at which the HOA and BBOA factors showed a clear separation from each other and from OOA. Six factors were recombined to make up the OOA factor. The BBOA and HOA factors used here are those from the 8-factor solution. More details can be found in the Supp. Material (Sect. S6).

The third method used to estimate the biomass burning contribution is based on receptor modeling of offline filter $\mathrm{PM}_{1}$ data. The offline dataset is discussed in detail elsewhere (Pandolfi et al., 2011b). Briefly, $12 \mathrm{~h} \mathrm{PM} \mathrm{PM}_{1}$ samples were collected on quartz fiber filters (Munktell) using DIGITEL DHA-80 high volume $\left(30 \mathrm{~m}^{3} \mathrm{~h}^{-1}\right)$ samplers. Major and trace elements, some ions, and nitrate, sulfate, ammonium and chloride concentrations were determined following the procedure described in Querol et al. (2001). OC and EC concentrations were measured by a Sunset laboratory instrument (results inter-compared in Sect. 2.2, reported as Sunset2). Positive Matrix Factorization (PMF by means of the ME-2 scripting; Paatero, 1999; Amato et al., 2009) was applied to this dataset. Species included in the PMF can be found in Fig. S6. Results are referred to in this study as PMF-OF (OF standing for offline filter dataset). Details on the receptor model and individual uncertainties are available in Amato et al. (2009). This method provides, among other data products, 
an estimate of the biomass burning contribution to bulk submicron OC. Nevertheless, the model was not able to identify the biomass burning source in BCN, as explained in Sect. 3.7. At MSY, the solution chosen had 6 factors (mineral, anthropogenic, sea salt, biomass burning, secondary sulfate, and secondary nitrate). The source profile of the biomass burning source can be found in Fig. S6.

Finally, the correlations of the different biomass burning $\mathrm{OA}$ estimates and tracers with $\mathrm{EC}_{\mathrm{bb}}$ (which is the most direct biomass burning tracer) were evaluated. PMF-AMS BBOA was used for DAURE-W. Levoglucosan concentrations (average of lev-HAS and lev-ISAC data sets) were used for DAURE-W. Acetonitrile concentrations measured by a High Sensitivity Proton Transfer Reaction Quadrupole Mass Spectrometer (PTR-MS; Lindinger et al., 1998) at BCN in DAURE-W and DAURE-S, and by a Proton Transfer Reaction Time of Flight (PTR-TOF, Graus et al., 2010; Müller et al., 2010) at MSY in DAURE-W were used. Submicron potassium $(\mathrm{K})$ concentrations were used for DAURE-W and DAURE-S. K concentrations were part of the PMF-OF dataset discussed above (Pandolfi et al., 2011b). Soluble K concentrations were determined in water extractions of the same samples and they were very similar to total K concentrations. Hence, total K concentrations were used. Although some biomass burning estimates reported in literature are based on $\mathrm{K}$, several recent studies have concluded that fine $\mathrm{K}$ can in some instances be dominated by other sources and can be a poor tracer for biomass burning (Zhang et al., 2010; Aiken et al., 2010).

\section{Results and discussion}

\subsection{EC and OC concentrations}

The carbonaceous aerosol at $\mathrm{BCN}$ and MSY during the DAURE campaigns showed differences in concentration, fractional composition, and source influences (Figs. 1 and 2). At BCN, the contribution of EC to total carbon was substantially higher than at MSY both in DAURE-W and DAURE-S, representing, on average, $32-37 \%$ at $\mathrm{BCN}$ and $15-16 \%$ at MSY. Conversely, the OC fractional contribution was higher at MSY than at BCN (Fig. 1), although the absolute concentrations of OC were higher at BCN (Fig. 2) during DAURE$\mathrm{W}$, and similar to those at MSY in DAURE-S. OC/EC average ratios (1.7-2.1 at BCN and 5.3-5.8 at MSY) were similar and lower, respectively, than those reported by previous studies at the same sampling sites (2.5 for $\mathrm{PM}_{1}$ at $\mathrm{BCN}$ and 11 for $\mathrm{PM}_{2.5}$ at MSY; Pérez et al., 2008b; Pey et al., 2009).

\subsection{EC sources}

During the winter period, $\mathrm{EC}_{\mathrm{f}}$ accounted for $87 \pm 1 \%$ (average \pm propagated measurement uncertainty of only ${ }^{14} \mathrm{C}$ measurements) of $\mathrm{EC}$ at $\mathrm{BCN}$, whereas at MSY this percentage was $66 \pm 3 \%$. In summertime, these values were $91 \pm 1 \%$ and $79 \pm 4 \%$ at BCN and MSY, respectively. As explained
DAURE-Winter
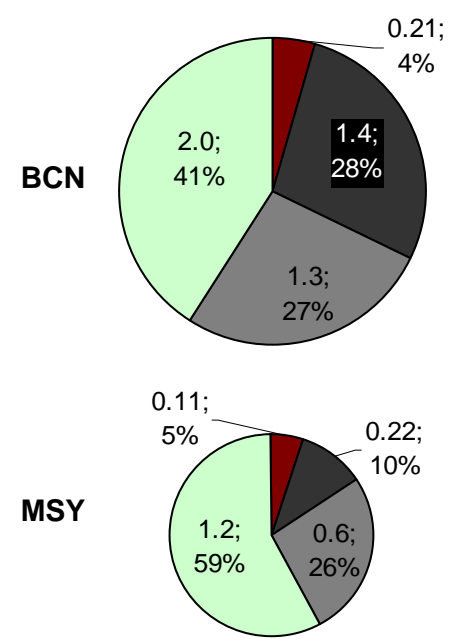

$\square \mathrm{EC}_{\mathrm{nf}} \quad \square \mathrm{EC}_{\mathrm{f}} \quad \square \mathrm{OC}_{\mathrm{f}} \quad \square \mathrm{OC}_{\mathrm{nf}}$

0.06
DAURE-Summer
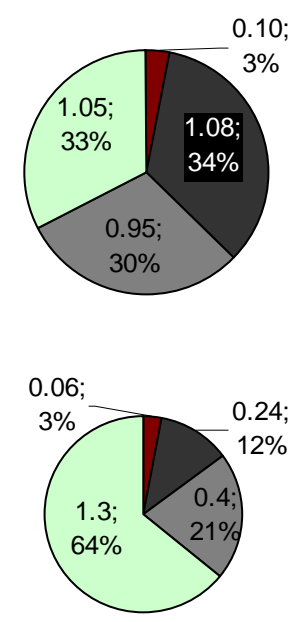

Fig. 1. Fossil (f) and non-fossil (nf) fractions of total carbon; concentrations in $\mu \mathrm{g} \mathrm{m}^{-3}$ and $\%$ of total carbon.

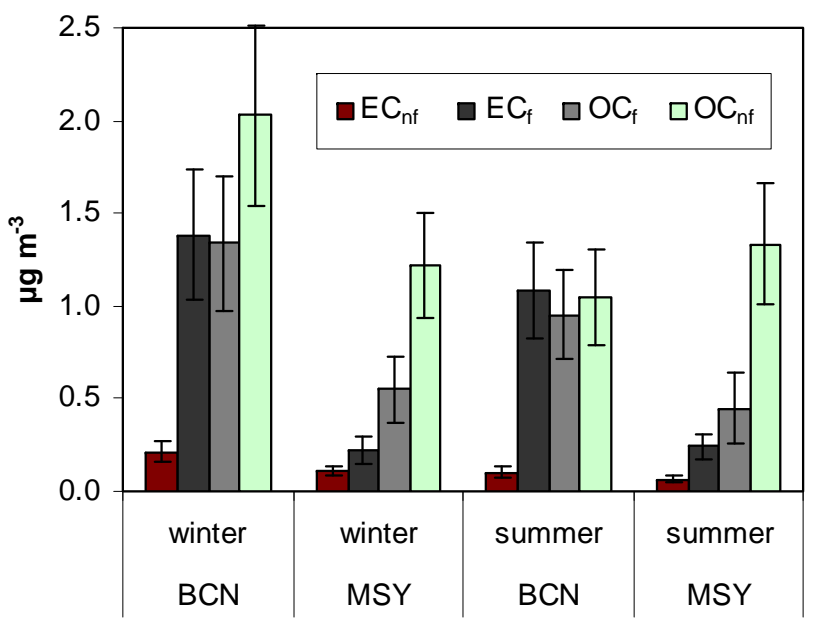

Fig. 2. Average absolute concentrations of the fossil (f) and nonfossil (nf) fractions of EC and OC $\left(\mu \mathrm{g} \mathrm{m}^{-3}\right)$.

above, $\mathrm{EC}_{\mathrm{f}}$ is attributed to fossil fuel combustion, mostly road traffic, and $\mathrm{EC}_{\mathrm{nf}}$ to biomass burning.

The high contribution of fossil fuel combustion to EC concentrations in BCN is in agreement with Pérez et al. (2010) and Reche et al. (2011), who found that black carbon concentrations varied mainly according to road traffic conditions. In both seasons, the $\mathrm{EC}_{\mathrm{f}}$ contribution to $\mathrm{EC}$ at the urban site is higher than at the rural site, as expected. In absolute values, the difference is larger. $\mathrm{EC}_{\mathrm{f}}$ at $\mathrm{BCN}$ was 6.3 times higher than at MSY in winter and 4.5 times higher in 
summer (Fig. 2). This is consistent with the BCN/MSY ratios found for $\mathrm{NO}_{\mathrm{x}}$ concentrations, 9 and 6 for winter and summer, respectively, although the instruments do not measure purely $\mathrm{NO}_{\mathrm{x}}$ and also include some of the more oxidized nitrogen species $\left(\mathrm{NO}_{\mathrm{z}}\right.$, Steinbacher et al., 2007; Dunlea et al., 2007). Assuming that a substantial fraction of the $\mathrm{NO}_{\mathrm{x}}$ at MSY comes from the coastal polluted regions similar to the $\mathrm{BCN}$ urban area, these ratios can be considered estimates of the dilution of urban and regional pollution during transport to MSY. CO concentrations were not available for comparison. The fact that the ratios are higher for $\mathrm{NO}_{\mathrm{x}}$ than $\mathrm{EC}$ is consistent with the fact that $\mathrm{NO}_{\mathrm{x}}$ is a reactive tracer with a lifetime on the order of 1 day and some of the reaction products $\left(\mathrm{HNO}_{3}\right)$ deposit very quickly to the surface and are not sampled by $\mathrm{NO}_{\mathrm{x}}$ analyzers, while $\mathrm{EC}$ is unreactive. The higher contributions of $\mathrm{EC}_{\mathrm{nf}}$ in winter with respect to summer are likely due to higher emissions from residential heating and open burning of agricultural biomass (banned by law from 15 March to 15 October, Spanish Decreto 64/1995), as wild fires are expected to make a low contribution, with the exception of infrequent short impact periods (Fig. S7).

\subsection{Fossil vs. contemporary OC}

During the winter period, $\mathrm{OC}_{\mathrm{f}}$ (thought to be mainly due to road traffic, as explained above) was $40 \pm 4 \%$ of OC at BCN and $31 \pm 4 \%$ at MSY. These values are similar to those obtained during winter at Zurich, Switzerland $\left(32 \% \mathrm{OC}_{\mathrm{f}} / \mathrm{OC}\right.$, Szidat et al., 2006), and at Göteborg, Sweden (35-45\% at an urban site and 35-40\% at a rural site, Szidat et al., 2009). A priori, it could be expected that fossil sources may have a higher influence in Spain due to the lesser use of wood burning for residential heating (less than $1 \%$ of the heating energy, INE, 2001). On the other hand, biogenic SOA may be higher under milder Spanish winter conditions compared to Switzerland or Sweden since the temperatures are higher, and biogenic volatile organic compounds (VOCs) emissions still occur in winter albeit at lower intensity than in summer (Seco et al., 2011). Therefore the differences in both sources may compensate each other, leading to similar $\mathrm{OC}_{\mathrm{f}}$ fractions.

In summer $\mathrm{OC}_{\mathrm{f}}$ was $48 \pm 4 \%$ of $\mathrm{OC}$ at $\mathrm{BCN}$ and $25 \pm 5 \%$ at MSY; this again being comparable to contributions at Göteborg, Sweden, in summer (31-47 \%, Szidat et al., 2009). Summer results for $\mathrm{BCN}$ (with the highest $\mathrm{OC}_{\mathrm{f}}$ fraction from the present study) are comparable to results from Mexico City (49-62\%, Aiken et al., 2010). Absolute $\mathrm{OC}_{\mathrm{f}}$ concentrations in winter were higher than in summer (by $0.4 \mu \mathrm{g} \mathrm{m}^{-3}$ ) at BCN. This was likely due to stronger accumulation of pollutants during the cold season with lower atmospheric dispersion, and perhaps to higher fossil combustion such as for residential heating.

At MSY, OC concentrations were similar for both seasons (Fig. 2). The ratio BCN/MSY for $\mathrm{OC}_{\mathrm{f}}$ concentrations was 2.1-2.4, which is lower than the corresponding ratio for $\mathrm{EC}_{\mathrm{f}}$ mentioned above (4.5-6.3). This is consistent with formation of fossil SOA during transport from urban and regional sources to the MSY site, and also consistent with the higher $\mathrm{NO}_{\mathrm{x}}$ ratios discussed above. Further evidence is provided by the comparison of the ratios of $\mathrm{OC}_{\mathrm{f}} / \mathrm{EC}_{\mathrm{f}}$ for both sites. The average ratio \pm standard deviation (variability) was $1.0 \pm 0.1$ in winter and $0.9 \pm 0.2$ in summer at BCN, and $2.6 \pm 0.7$ in winter and $1.8 \pm 0.5$ in summer at MSY. The error for MSY in summer (0.5) is the propagated measurement uncertainty, since no variability is available because there was only one pooled sample for EC. The low variability of the ratios in $\mathrm{BCN}$ suggests that the $\mathrm{OC}_{\mathrm{f}}$ is mainly primary, or that the secondary fraction changes little, e.g. if it is formed fast enough (Robinson et al., 2007; Chirico et al., 2010) so that it still correlates with the $\mathrm{EC}_{\mathrm{f}}$. This is also supported by the good correlation between $\mathrm{OC}_{\mathrm{f}}$ and $\mathrm{EC}_{\mathrm{f}}\left(R^{2}=0.81\right.$, Fig. S8). At MSY the larger ratios indicate that a substantial fraction of the $\mathrm{OC}_{\mathrm{f}}$ may be due to fossil SOA formation driven by photochemical reactions during the transport to the rural site. The larger variability of the $\mathrm{OC}_{\mathrm{f}} / \mathrm{EC}_{\mathrm{f}}$ at MSY, although partially due to the relatively high measurement uncertainty, indicates that the formation of fossil SOA may be more variable. The difference in the ratio in winter and summer at MSY is not significant due to the high uncertainties.

$\mathrm{OC}_{\mathrm{nf}}$ at $\mathrm{BCN}$ was twice as high in winter than in summer. This can be attributed to a higher contribution of biomass burning and reduced mixing in winter with respect to summer in the Barcelona region, as indicated by the fact that $\mathrm{EC}_{\mathrm{nf}}$ was also twice as high in winter. At MSY, $\mathrm{OC}_{\mathrm{nf}}$ was similar in summer and winter, despite the lower biomass burning contribution in summer as evidenced by the lower $\mathrm{EC}_{\mathrm{nf}}$. This can likely be explained by a higher contribution of biogenic SOA in summer, due to higher biogenic emissions and enhanced photochemistry. Seco et al. (2011) report summer/winter ratios of $\sim 10$ for biogenic VOCs ambient concentrations at the rural site.

\subsection{Further source apportionment of the non-fossil OC}

$\mathrm{OC}_{\mathrm{nf}}$ can be apportioned to the different sources with some additional assumptions. The estimations carried out in the present study include biomass burning $\left(\mathrm{OC}_{\mathrm{bb}}\right)$, biogenic SOA $\left(\mathrm{OC}_{\mathrm{bio}}\right)$ and other non-fossil contributions called in this study as urban non-fossil OC ( $\left.\mathrm{OC}_{\text {urb-nf }}\right)$, such as cooking and tire wear. Results are shown in Fig. 3. $\mathrm{OC}_{\mathrm{bb}}$ was estimated with the method described in Sect. 2.4 (Eq. 2). $\mathrm{OC}_{\mathrm{bb}}$ is estimated to account for $30-35 \%$ of the $\mathrm{OC}_{\mathrm{nf}}$ at both sites and seasons (17-21\% of total OC), with the exception of MSY in summer, where it only accounted for $16 \%$ of the $\mathrm{OC}_{\mathrm{nf}}(12 \%$ of total OC). The contribution from $\mathrm{OC}_{\text {urb-nf }}$ was calculated from the $\mathrm{OC}_{\mathrm{f}}$ contribution, based on the assumption that $\mathrm{OC}_{\text {urb-nf }}$ is $\sim 20 \%$ of the total urban $\mathrm{OC}$ contribution $\left(\mathrm{OC}_{\mathrm{f}}+\mathrm{OC}_{\mathrm{urb}-\mathrm{nf}}\right)$ (Hildemann et al., 1994; Hodzic et al., 2010). OC $_{\text {urb-nf }}$ was estimated as $0.2-0.3 \mu \mathrm{g} \mathrm{m}^{-3}$ at $\mathrm{BCN}$, which is $16-23 \%$ of the $\mathrm{OC}_{\mathrm{nf}}$ $\left(10-12 \%\right.$ of total OC). At MSY, the $\mathrm{OC}_{\mathrm{urb}-\mathrm{nf}}$ was lower ( 0.14 and $0.11 \mu \mathrm{g} \mathrm{m}^{-3}$ in winter and summer, respectively, 


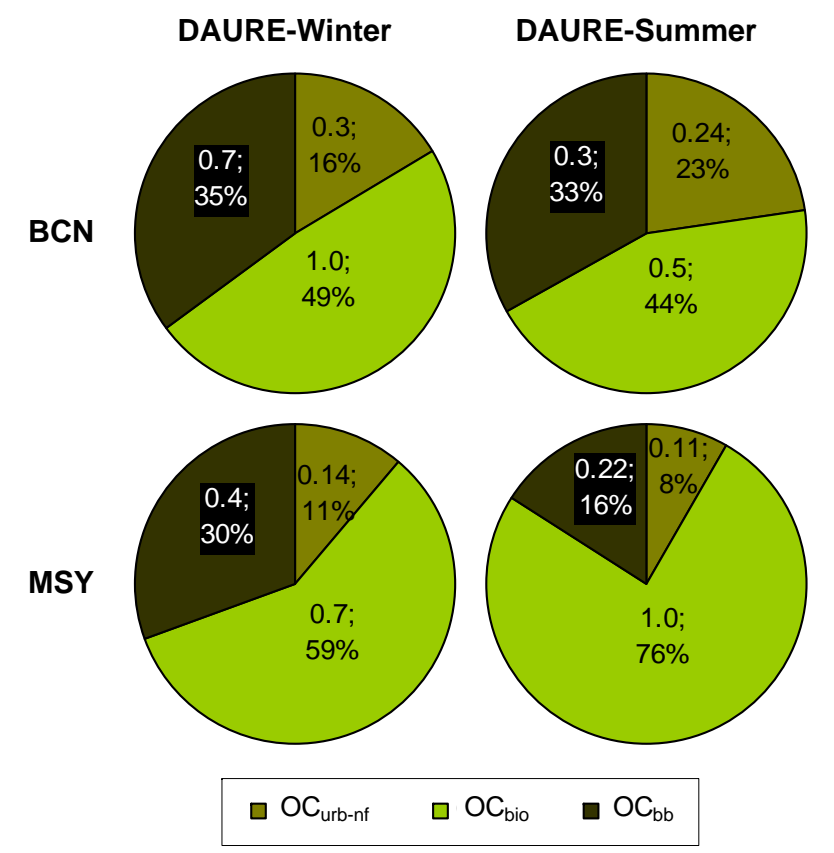

Fig. 3. Source apportionment to non-fossil organic carbon $\left(\mu \mathrm{g} \mathrm{m}^{-3}\right)$. $\mathrm{OC}_{\mathrm{urb}-\mathrm{nf}}$ : urban nonfossil organic carbon; $\mathrm{OC}_{\mathrm{bio}}$ : biogenic organic carbon; $\mathrm{OC}_{\mathrm{bb}}$ : biomass burning organic carbon.

$8-11 \%$ of the $\mathrm{OC}_{\mathrm{nf}}, 6-8 \%$ of total $\left.\mathrm{OC}\right)$. As discussed above, $\mathrm{OC}_{\mathrm{urb}-\mathrm{nf}}$ may be underestimated if recent studies of a cooking contribution similar to the traffic OC contribution are applicable to this region. A sensitivity test was carried out to check the changes that would result from an assumption of $\mathrm{OC}_{\text {urb-nf }} /\left(\mathrm{OC}_{\mathrm{f}}+\mathrm{OC}_{\text {urb-nf }}\right)$ of $10 \%$ or $30 \%$, instead of the aforementioned $20 \%$. The $\mathrm{OC}_{\mathrm{urb}-\mathrm{nf}}$ contribution changes by $56-71 \%$, although in absolute concentration the change is very low. The $\mathrm{OC}_{\text {bio }}$ contribution was slightly higher in summer $\left(1.0 \mu \mathrm{g} \mathrm{m}^{-3}\right)$ than in winter $\left(0.7 \mu \mathrm{g} \mathrm{m}^{-3}\right)$ at MSY, while $\mathrm{OC}_{\text {bio }}$ was lower in summer at $\mathrm{BCN}$. The same sensitivity test showed that $\mathrm{OC}_{\text {bio }}$ contribution changes by 6 $37 \%$, when changing the $\mathrm{OC}_{\mathrm{urb}-\mathrm{nf}} /\left(\mathrm{OC}_{\mathrm{f}}+\mathrm{OC}_{\mathrm{urb}-\mathrm{nf}}\right.$ ratio from $20 \%$ to $10-30 \%$, with the main conclusions remaining the same. The absence of a strong increase in $\mathrm{OC}_{\text {bio }}$ concentration between winter and summer, compared to a factor of 10 increase in biogenic VOCs is very surprising. Although a larger fraction of the biogenic SOA species may remain in the gas-phase in the summer compared to the winter, this effect is thought to be small (e.g. Martin et al., 2010). This disagreement remains unexplained with the tools available at the moment, and further research will be needed to find out the possible causes, but it highlights the uncertainties in the estimation methods.

\subsection{Day-to-day variation}

There was only moderate day-to-day variation in the fractional contributions to TC throughout the winter period.
The fossil fraction of $\mathrm{TC}\left(\mathrm{TC}_{\mathrm{f}}\right)$ ( $48 \mathrm{~h}$ averages) varied between $42-68 \%$ at $\mathrm{BCN}$ and between $27-50 \%$ at MSY (Fig. 4). The different meteorological scenarios during the campaign are described in detail by Pandolfi et al. (2011b). Briefly, there were three types of scenarios during winter: (A) characterized by recirculation of air masses and accumulation of pollutants with both MSY and BCN within the mixing layer; (B) when the mixing layer height was very low and hence MSY was above it; and (C) with Atlantic advection which resulted in flushing pollutants from the region. There were some transition periods between different scenarios indicated as $T$ in Fig. 4. Note that due to the sampling periods ( $48 \mathrm{~h}$ in winter and $24 \mathrm{~h}$ in summer) more than one type of scenario may correspond to a single sample. In these cases the prevailing scenario is given in bold in Fig. 4 .

Samples from $17 / 03$ to $25 / 03$ were collected during periods with prevailing scenario A conditions. For those samples TC concentrations at $\mathrm{BCN}$ were about twice those at MSY. The $\mathrm{TC}_{\mathrm{f}}, \mathrm{EC}_{\mathrm{f}}$ and $\mathrm{OC}_{\mathrm{f}}$ contributions at $\mathrm{BCN}$ and MSY for these samples were highly correlated $\left(R^{2}=0.83-0.98\right.$; Fig. 5). When $\mathrm{TC}_{\mathrm{f}}$ was more dominant at $\mathrm{BCN}(19 / 03-21 / 03$, $68 \%$ of TC), the contribution of $\mathrm{TC}_{\mathrm{f}}$ at MSY increased with respect to the rest of the days (reaching 50\%). Conversely, when $\mathrm{TC}_{\mathrm{f}}$ showed a lower contribution at $\mathrm{BCN}(21 / 03-23 / 03$ and $23 / 03-25 / 03 ; 42 \%$ and $45 \%$, respectively), $\mathrm{TC}_{\mathrm{f}}$ was also lower at MSY (32\%) (Fig. 4a and b), which reflects the stronger coupling of both sites due to the shared mixed layer.

Under scenario B conditions, concentrations of TC at BCN were about 3 times those at MSY and the fractional contributions were different, consistent with the meteorological characterization of a decoupling between the two sites. There was no correlation for the samples collected under scenario

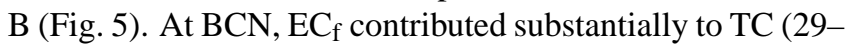
$30 \%$ ), whereas at MSY its contribution was lower as typical for this site (9-13\%) and $\mathrm{OC}_{\mathrm{nf}}$ accounted for more than $50 \%$ of TC (Fig. 4a and b).

During the summer campaign, a time-resolved comparison of $\mathrm{TC}_{\mathrm{f}}$ between both sites is not possible due to the lack of time-resolved data for the EC fractions at MSY, as explained above. $\mathrm{TC}_{\mathrm{f}}$ varied between $47-75 \%$ at BCN (Fig. $4 \mathrm{c}$ and d). The different meteorological scenarios during the summer campaign are described in detail by Pandolfi et al. (2011). Briefly, scenario D was characterized by regional pollution; $\mathrm{E}$ was characterized by Atlantic advection (similar to winter scenario $\mathrm{C}$ ); and $\mathrm{F}$ was influenced by air masses coming from North Africa. Even though 09/07-10/07 and 11/07-12/07 samples were collected under the same type of scenario (D scenario), the first sample showed TC concentrations at BCN 3 times those at MSY, whereas for the second sample the concentrations were similar between sites, suggesting some variability in dispersion between those periods. For the rest of the samples, collected under scenario F, the fractional contribution variations were similar at MSY and $\mathrm{BCN}$, although there was not a clear correlation in concentrations as that found for winter (Fig. S9). 

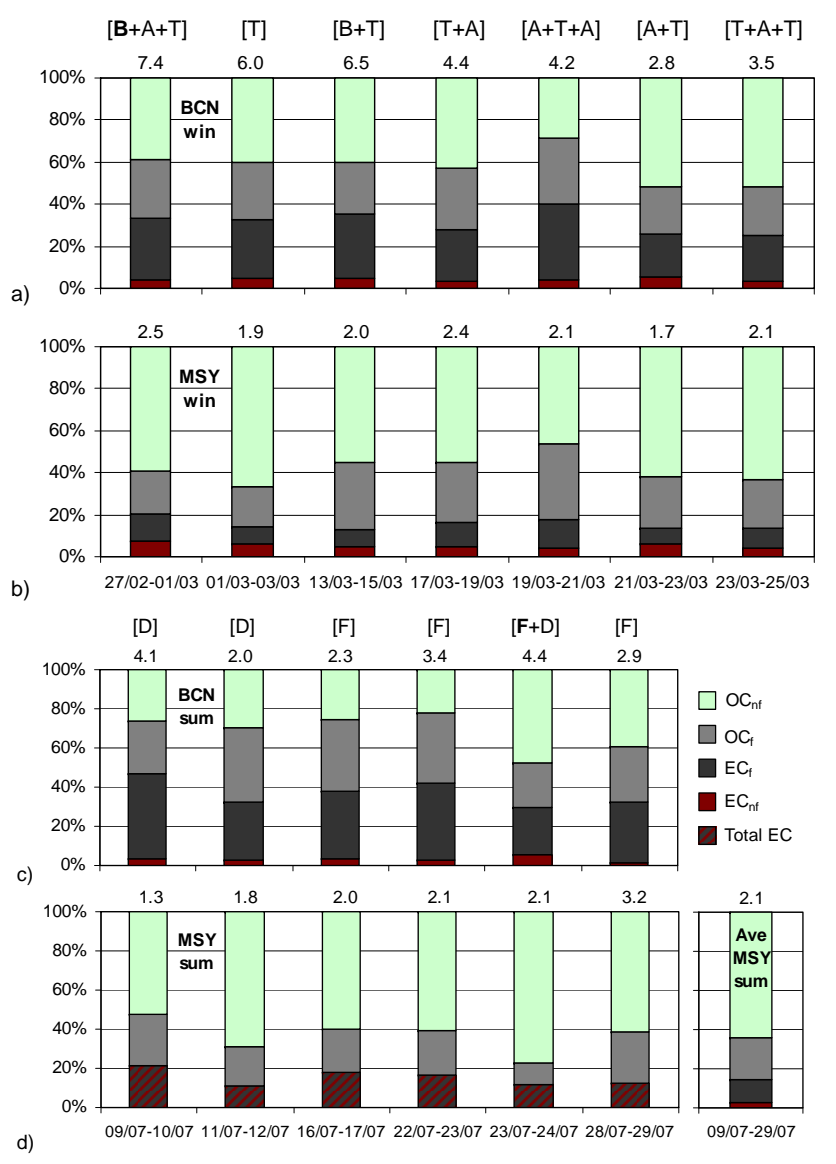

Fig. 4. Variation of the fossil (f) and non-fossil (nf) fractions of EC and OC during the study periods (date format: $\mathrm{dd} / \mathrm{mm}$ ). The atmospheric scenarios and the total carbon concentrations are listed on top of each bar in $\mu \mathrm{g} \mathrm{m}^{-3}$. Scenario A: air masses recirculation and accumulation of pollutants (MSY and BCN within the mixing layer); B: mixing layer height below MSY; D: regional pollution; F: air masses from North Africa; T: transition between different scenarios. In bold the prevailing scenario when more than one occurred during the same sampling period. (a) winter BCN; (b) winter MSY; (c) summer BCN; (d) summer MSY. For summer MSY, no distinction of $\mathrm{EC}_{\mathrm{f}} \mathrm{vs}$. $\mathrm{EC}_{\mathrm{nf}}$ is given for the individual days, because samples were pooled for analyses (see text).

\subsection{Combination of ${ }^{14} \mathrm{C}$ and PMF-AMS results}

A comparison of the relative contributions to $\mathrm{OC}$ determined by the ${ }^{14} \mathrm{C}$ and PMF-AMS techniques is shown in Fig. 6 (DAURE-W only). We compare fractional contributions as they should not be affected by concentration inaccuracies in either method. To compare the results from the ${ }^{14} \mathrm{C}$ method to PMF-AMS measurements, OC was calculated from PMFAMS OM as explained in Sect. 2.2. These calculations result in hydrocarbon-like organic carbon (HOC), cooking organic carbon (COC), biomass burning organic carbon (BBOC), and oxygenated organic carbon (OOC) contributions. To facilitate comparison to ${ }^{14} \mathrm{C}$ results, the sources identified by

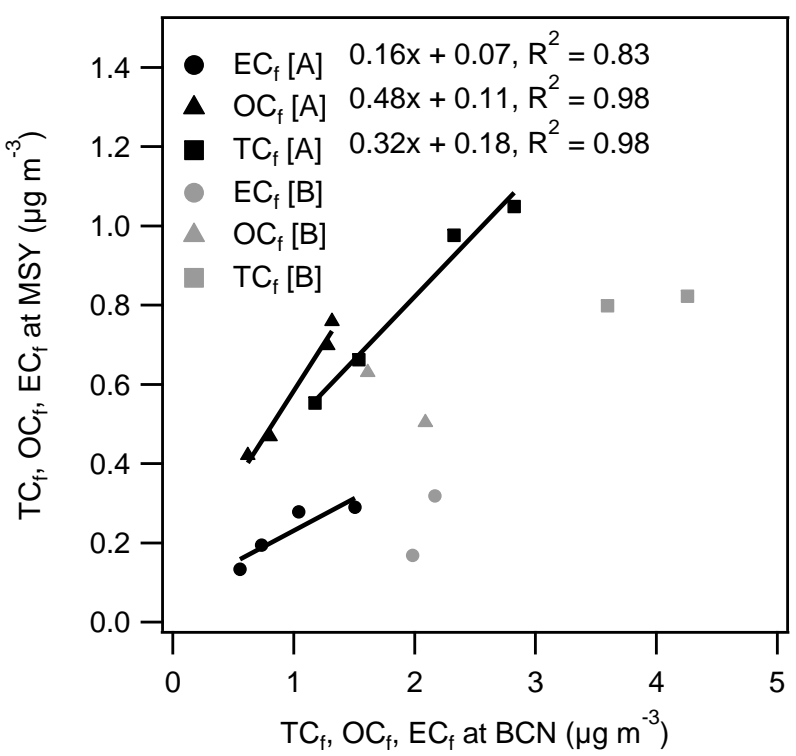

Fig. 5. $\mathrm{TC}_{\mathrm{f}}, \mathrm{EC}_{\mathrm{f}}$ and $\mathrm{OC}_{\mathrm{f}}$ contributions at $\mathrm{MSY}$ vs. $\mathrm{TC}_{\mathrm{f}}, \mathrm{EC}_{\mathrm{f}}$ and $\mathrm{OC}_{\mathrm{f}}$ contributions at $\mathrm{BCN}$ during scenario (A) and during scenario (B). Lines and equations correspond to orthogonal distance regressions.

PMF-AMS were divided into fossil and non-fossil. HOC from BCN was included in the fossil sources. For MSY, HOC was assumed to be $80 \%$ of fossil origin $\left(\mathrm{HOC}_{\mathrm{f}}\right)$ and $20 \%$ from urban non-fossil sources ( $\mathrm{HOC}_{\mathrm{nf}}$ ) (based on Hildemann et al., 1994). COC and BBOC were included in the nonfossil sources. As OOC is thought to be a surrogate for total secondary OC and originates from both fossil and contemporary sources, OOC was divided in fossil and non-fossil $\left(\mathrm{OOC}_{\mathrm{f}}\right.$ and $\left.\mathrm{OOC}_{\mathrm{nf}}\right)$ according to the $\mathrm{OC}_{\mathrm{f}} / \mathrm{OC}_{\mathrm{nf}}$ ratio identified by the ${ }^{14} \mathrm{C}$ method, so that the resulting total $\mathrm{OC}_{\mathrm{f}} / \mathrm{OC}_{\mathrm{nf}}$ ratio from PMF-AMS sources equals the $\mathrm{OC}_{\mathrm{f}} / \mathrm{OC}_{\mathrm{nf}}$ ratio from the ${ }^{14} \mathrm{C}$ method.

At $\mathrm{BCN}, \mathrm{OC}_{\mathrm{f}}$ is estimated to be $\sim 53 \%$ secondary, and the remaining fraction of the $\mathrm{OC}_{\mathrm{f}}$ in $\mathrm{BCN}$ is estimated to be primary $(\sim 47 \%)$. This fossil secondary percentage is relatively low when compared to findings from Robinson et al. (2007), who predict a high proportion of SOA formation from vehicle emissions. $\mathrm{OC}_{\mathrm{nf}}$ is a combination of $\mathrm{COC}, \mathrm{OOC}_{\mathrm{nf}}$ and primary BBOC. OOC, a surrogate for total secondary OC, is mostly non-fossil ( $\sim 60 \%$ ), with this fraction being due to biogenic sources, biomass burning, and urban non-fossil sources.

At MSY, $\mathrm{OC}_{\mathrm{f}}$ is estimated to be $\sim 85 \%$ secondary. This is consistent with previous conclusions based on the higher $\mathrm{OC}_{\mathrm{f}} / \mathrm{EC}_{\mathrm{f}}$ ratio at MSY than at BCN (see Sect. 3.3), which also indicated a higher contribution of fossil SOA at MSY. Like at $\mathrm{BCN}$, the OOC determined with the AMS is mostly non-fossil $(\sim 70 \%)$, and may have different origins such as biogenic sources or biomass burning. Hence, the combination of both techniques allows a better characterization of 

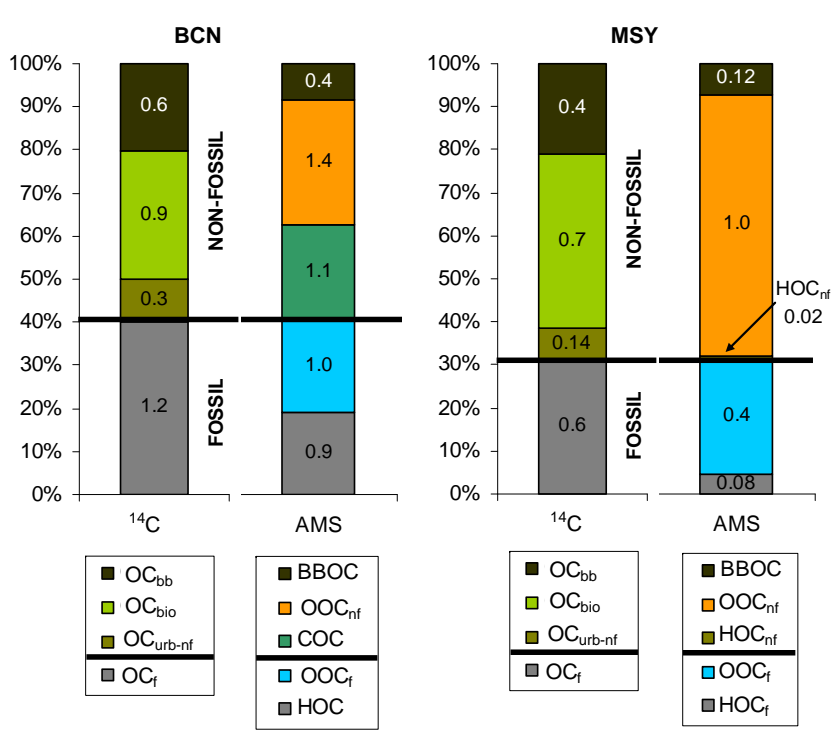

Fig. 6. Relative source apportionment to organic carbon during DAURE-W according to the ${ }^{14} \mathrm{C}$ technique and PMF results of AMS measurements. Numbers indicate the absolute concentrations in $\mu \mathrm{g} \mathrm{m}^{-3}$. BCN averages exclude $01 / 03-03 / 03$ and 13/0315/03 samples because of low availability of AMS data. HOC: hydrocarbon-like organic carbon; OOC: oxygenated organic carbon (secondary); COC: cooking organic carbon; BBOC: primary biomass burning organic carbon; $\mathrm{OC}_{\mathrm{urb}-\mathrm{nf}}$ : urban non-fossil organic carbon.

the carbonaceous aerosol sources, distinguishing the primary and secondary contributions. These conclusions remain the same if the aforementioned assumed $80 \%$ fossil origin of HOC changes from $70 \%$ to $90 \%$.

\subsection{Comparison of biomass burning OC determined by different approaches}

In Fig. 7 we compare the biomass burning $\mathrm{OC}\left(\mathrm{OC}_{\mathrm{bb}}\right)$ concentrations during winter estimated using the ${ }^{14} \mathrm{C}$ data with those from several other techniques, including PMFAMS, PMF-OF, and the tracer-based method using levoglucosan. Note that for the results from the PMF-AMS and levoglucosan methods the concentrations refer to only primary BBOC (Grieshop et al., 2009; DeCarlo et al., 2010). No biomass burning source was identified at BCN by PMF$\mathrm{OF}$ although this technique enabled identification of such a source at MSY. Lack of identification at BCN may be due to the presence of multiple additional sources, which complicate the identification of relatively small sources (the relative contribution of BBOC to OC was lower than that at MSY according to AMS-PMF results).

Biomass burning contributions estimated by the ${ }^{14} \mathrm{C}$ technique are similar or in most cases slightly higher than those from other techniques, with the exception of the three first samples at BCN (Fig. 7). The difference compared to the
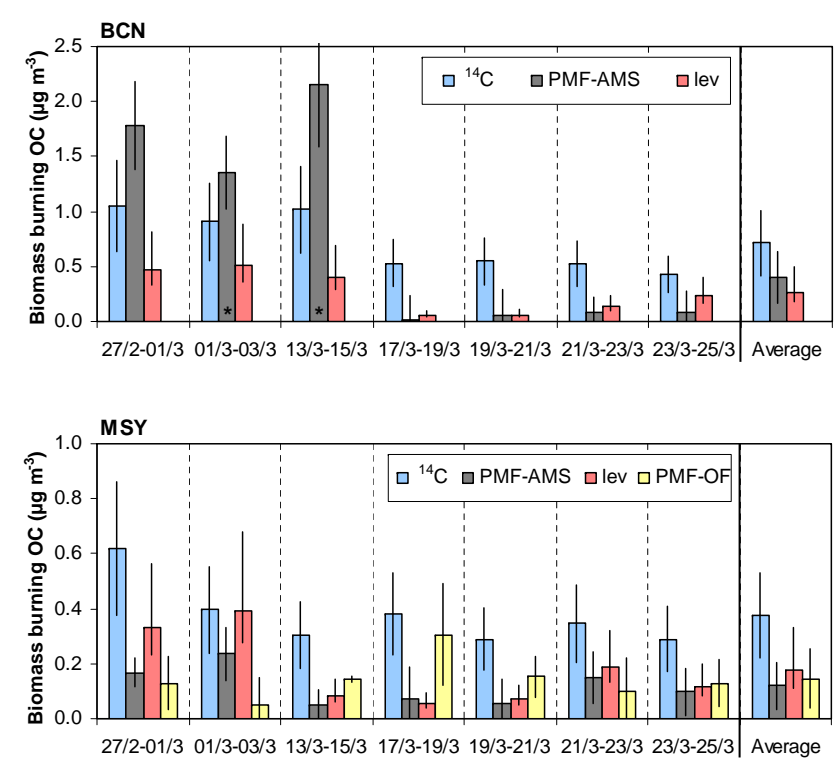

Fig. 7. Concentrations of $\mathrm{OC}$ due to biomass burning $\left(\mu \mathrm{g} \mathrm{m}^{-3}\right)$ estimated with different methods: the ${ }^{14} \mathrm{C}$ technique, PMF-AMS, levoglucosan-tracer method, and PMF-OF. *: low AMS data availability for the $48 \mathrm{~h}$ period. Error bars in the ${ }^{14} \mathrm{C}$ technique account for the uncertainty of the ${ }^{14} \mathrm{C}$ method and the uncertainty of the $(\mathrm{EC} / \mathrm{OC})_{\text {bbe }}$ ratio (from 0.2 to 0.4 ); error bars in the PMF-AMS are an estimation of the uncertainty of the biomass burning contribution; error bars in the levoglucosan-tracer method reflect the variability of the (lev/OC) bbe ratio from 0.07 to 0.17 ; error bars in the PMF-OF are standard deviation of the four $12 \mathrm{~h}$ samples included in each of the $48 \mathrm{~h}$ average periods. Date format: $\mathrm{dd} / \mathrm{m}$.

AMS and levoglucosan results may be partially explained by the presence of biomass burning SOC, which is not included in the $\mathrm{OC}_{\mathrm{bb}}$ calculated using these methods, and would be expected to be $\sim 25 \%$ of POA (Cubison et al., 2011). It is also possible that the biomass burning $\mathrm{OC}$ contribution estimated by the ${ }^{14} \mathrm{C}$ method is overestimated, if the $(\mathrm{EC} / \mathrm{OC})_{\text {bbe }}$ assumed for our calculations is too low for the biomass burning taking place in the study area. Nevertheless, the different estimates follow the same time trend, with the exception of PMF-OF. Thus it appears that PMF-OF is less accurate in the retrieval of this source. The biomass burning source profile determined by PMF-OF can be found in Fig. S6.

It is of interest to further evaluate the similarities of the different biomass burning estimation methods and tracers, without the possible systematic uncertainties associated with the conversion factors used to estimate the $\mathrm{OC}_{\mathrm{bb}}$ from different tracers (such as $(\mathrm{EC} / \mathrm{OC})_{\mathrm{bbe}}$, (lev/OC) $)_{\mathrm{bbe}}$, and OM/OC for biomass burning). Scatter plots of the different tracers and estimates are shown in Fig. 8. BBOA estimated by PMFAMS correlates well with $\mathrm{EC}_{\mathrm{bb}}\left(R^{2}=0.83\right.$, using all samples), as seen in Fig. 8a. The correlation of levoglucosan concentrations with $\mathrm{EC}_{\mathrm{bb}}$ shows an $R^{2}=0.57$ with a slope of 0.20 using all samples (Fig. 8b). The slope is the lev/EC $\mathrm{bb}$ 

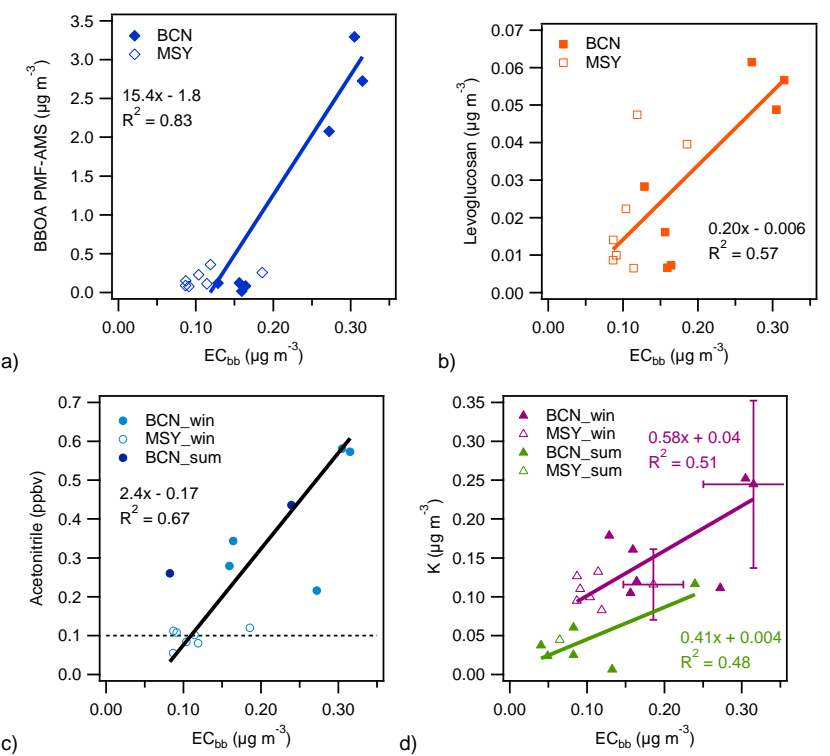

Fig. 8. Scatter plot of (a) biomass burning organic aerosol contribution estimated from PMF-AMS vs. biomass burning elemental carbon estimated by ${ }^{14} \mathrm{C}$ method $\left(\mathrm{EC}_{\mathrm{bb}}\right)$ in DAURE-W; (b) levoglucosan concentrations (average of lev-HAS and lev-ISAC measurements) vs. $\mathrm{EC}_{\mathrm{bb}}$ in DAURE-W; (c) $\mathrm{K}$ concentrations vs. $\mathrm{EC}_{\mathrm{bb}}$ in DAURE-W (purple) and DAURE-S (green), error bars indicate measurement uncertainty, only shown for two data points for clarity; (d) acetonitrile concentrations vs. $\mathrm{EC}_{\mathrm{bb}}$ in DAURE-W; dotted line indicates typical continental background acetonitrile concentrations (although lower background values are possible for air with recent contact with the ocean). Correlation coefficients were calculated using all data points shown in the plots. Regression lines were calculated with orthogonal distance regressions.

ratio, which is in the lower range of the lev/EC $\mathrm{bb}_{\mathrm{b}}$ values found in the literature, which vary from 0.15 to 2 in most cases (Schmidl et al., 2008; Sullivan et al., 2008; Gonçalves et al., 2010; Saarnio et al., 2010), although much higher values (up to 10 or 15) have also been reported (Fine et al., 2004; Sullivan et al., 2008). This may indicate lower initial emission ratios, or some oxidation or evaporation of levoglucosan during atmospheric transport.

Acetonitrile concentrations show correlation with $\mathrm{EC}_{\mathrm{bb}}$ $\left(R^{2}=0.67\right.$, Fig. 8c $)$. Although concentrations at MSY were close to typical acetonitrile continental background concentrations (e.g. Aiken et al., 2010), they are consistent with low $\mathrm{EC}_{\mathrm{bb}}$ concentrations.

$\mathrm{K}$ concentrations show lower correlation with $\mathrm{EC}_{\mathrm{bb}}$ for low concentrations (Fig. 8d), with $R^{2}=0.51$ in DAURE$\mathrm{W}$ and $R^{2}=0.48$ in DAURE-S. The winter data suggest the presence of a background level of bulk $\mathrm{K}$ (intercept when $\mathrm{EC}_{\mathrm{bb}}=0$ ) of $\sim 40 \mathrm{ng} \mathrm{m}^{-3}$, which may be due to sources other than biomass burning, such as food cooking (Hildemann et al., 1991; Schauer et al., 1999), vegetative detritus (Hildemann et al., 1991), fly ash (Lee and Pacyna 1999), and dust such as feldspars and clay minerals. This is consistent with findings by Zhang et al. (2010) and Aiken et al. (2010), and the latter authors reported a background non-biomass burning $\mathrm{K}$ concentration of $\sim 120 \mathrm{ng} \mathrm{m}^{-3}$ in Mexico City. Moreover, $\mathrm{K}$ emissions depend on the burning conditions. The influence of cooking on the $\mathrm{K}$ concentrations is supported by the higher $R^{2}(0.74)$ found for multilinear regression of $\mathrm{K}$ concentrations vs. BBOA and COA concentrations found by PMF-AMS at BCN, compared to the $R^{2}(0.54)$ for K concentrations vs. BBOA. Nevertheless, the noise in the $\mathrm{K}$ data is quite high (see measurement uncertainty as error bars for two data points in Fig. 8c), which should be considered when evaluating the robustness of the conclusions from these data. Therefore, given the moderate correlation of $\mathrm{K}$ with $\mathrm{EC}_{\mathrm{bb}}$ and the high uncertainty in $\mathrm{K}$ concentrations, $\mathrm{K}$ is not the best tracer for biomass burning emissions for the present study.

\section{Conclusions}

The contribution of EC to $\mathrm{TC}$ at $\mathrm{BCN}$ was substantially higher than at MSY both in the winter and the summer campaign. The OC contribution, although higher at MSY as a fraction of TC, was higher at $\mathrm{BCN}$ in absolute concentration.

At BCN, 87 and $91 \%$ of the EC, in winter and summer, respectively, had a fossil origin (mainly road traffic), whereas at MSY these percentages were 66 and $79 \%$, respectively. In absolute values, $\mathrm{EC}_{\mathrm{f}}$ at $\mathrm{BCN}$ was $4.5-6.3$ times that at MSY, which is in agreement with dilution ratios estimated from $\mathrm{NO}_{\mathrm{x}}$ concentrations. Higher concentrations of $\mathrm{EC}_{\mathrm{nf}}$ were found in winter than summer and attributed to a higher biomass burning contribution during winter.

The contribution of fossil sources to OC (mainly POA and SOA from road traffic) was $40 \%$ at BCN and $31 \%$ at MSY in winter, and $48 \%$ at BCN and $25 \%$ at MSY in summer. These values are similar to those observed in Zurich, Switzerland, and in Göteborg, Sweden. The highest contribution of fossil sources to total carbon found in the present study is similar to the average values from Mexico City. The absolute $\mathrm{OC}_{\mathrm{f}}$ concentrations in winter were slightly higher than in summer at $\mathrm{BCN}$ due to stronger accumulation of pollutants due to reduced dispersion, whereas at MSY the concentrations were similar for both seasons. By combining results from the ${ }^{14} \mathrm{C}$ and PMF-AMS techniques, we can estimate that the $\mathrm{OC}_{\mathrm{f}}$ at $\mathrm{BCN}$ is $\sim 47 \%$ primary. The formation of secondary $\mathrm{OC}_{\mathrm{f}}$ appears to be rapid enough that the $\mathrm{OC}_{\mathrm{f}} / \mathrm{EC}_{\mathrm{f}}$ stays about constant for the timescales of our samples. At MSY the $\mathrm{OC}_{\mathrm{f}}$ is mainly secondary ( $\sim 85 \%)$, as determined both by the high $\mathrm{OC}_{\mathrm{f}} / \mathrm{EC}_{\mathrm{f}}$ ratio at MSY, and the combination of ${ }^{14} \mathrm{C}$ and $\mathrm{PMF}-$ AMS results.

$\mathrm{OC}_{\mathrm{nf}}$ at $\mathrm{BCN}$ was higher in winter than in summer probably due to a higher contribution of biomass burning. At MSY, $\mathrm{OC}_{\mathrm{nf}}$ was higher in summer which is explained by a higher contribution of biogenic emissions (partially offset by decreased biomass burning). Nevertheless, the estimated biogenic secondary OC does not increase proportionally to the 
order-of-magnitude increase observed for biogenic volatile organic compounds (VOCs) between winter and summer, which highlights the uncertainties in the estimation of that component.

There was moderate day-to-day variation throughout the study periods (with the fossil contribution to total carbon being between $42-68 \%$ at $\mathrm{BCN}$ and $27-50 \%$ at MSY in winter, and between $47-75 \%$ at BCN in summer), but the differences between BCN and MSY in TC levels and source contributions depended largely on the meteorological conditions. Hence, during regional pollution accumulation episodes, concentrations and source distributions were similar at both sites; whereas during stagnation episodes when the boundary layer was below the MSY sampling site, the sites were decoupled and the total carbon levels and fossil sources contribution were higher at $\mathrm{BCN}$ than at MSY.

Biomass burning OC contributions estimated by the ${ }^{14} \mathrm{C}$ technique were similar or slightly higher than those from other techniques, nonetheless they were reasonably correlated. The difference with the PMF-AMS and levoglucosan method results could be partially explained by the contribution of SOA formed from biomass burning emissions (not included in the $\mathrm{OC}_{\mathrm{bb}}$ from these methods), and/or an overestimation of $\mathrm{OC}_{\mathrm{bb}}$ contribution due to a non-representative biomass burning EC/OC ratio used for the calculations. Bulk submicron $\mathrm{K}$ concentrations, although commonly used as tracer for biomass burning, appear influenced by additional sources other than biomass burning during winter, as observed in some previous studies. PMF-AMS BBOA and acetonitrile concentrations are the biomass burning markers that correlate better with $\mathrm{EC}_{\mathrm{bb}}$.

\section{Supplementary material related to this article is available online at: http://www.atmos-chem-phys.net/11/12067/2011/ acp-11-12067-2011-supplement.pdf.}

Acknowledgements. This work was supported by the Acción Complementaria DAURE CGL2007-30502-E/CLI, the GRACCIE project CSD2007-00067, the VAMOS project CGL201019464/CLI, and the Departament de Medi Ambient i Habitatge of the Generalitat de Catalunya. This work was also supported by the EU FP6 project EUCAARI and the IMBALANCE project within the Centre of Competence for Environment and Sustainability (CCES). M. C. Minguillón was partially supported by a Postdoctoral Grant in the frame of Programa Nacional de Movilidad de Recursos Humanos del Plan nacional de I-D+I 2008-2011 from the Spanish Ministry of Science and Innovation. D. A. Day, A. M. Ortega, and J. L. Jimenez were partially supported by US NSF grants ATM-0920940 and ATM-0919189 (from Atm. Chem. and OISE Office of International Science and Engineering), and by NOAA grant NA08OAR4310565. A. M. Ortega was supported by DOE SCGF (ARRA/ORISE/ORAU) Fellowship DE-AC05-06OR23100. J. Peñuelas and R. Seco were supported by the Spanish Government projects CGL2010-17172 and Consolider Ingenio Montes CSD2008-00040, and by a postdoctoral grant from Fundación
Ramón Areces to R. Seco. The National Center for Atmospheric Research is sponsored by the National Science Foundation.

Edited by: A. Petzold

\section{References}

Aiken, A. C., Decarlo, P. F., Kroll, J. H., Worsnop, D. R., Huffman, J. A., Docherty, K. S., Ulbrich, I. M., Mohr, C., Kimmel, J. R., Sueper, D., Sun, Y., Zhang, Q., Trimborn, A., Northway, M., Ziemann, P. J., Canagaratna, M. R., Onasch, T. B., Alfarra, M. R., Prevot, A. S. H., Dommen, J., Duplissy, J., Metzger, A., Baltensperger, U., and Jimenez, J. L.: O/C and OM/OC ratios of primary, secondary, and ambient organic aerosols with high-resolution time-of-flight aerosol mass spectrometry, Environ. Sci. Technol., 42, 4478-4485, 2008.

Aiken, A. C., de Foy, B., Wiedinmyer, C., DeCarlo, P. F., Ulbrich, I. M., Wehrli, M. N., Szidat, S., Prevot, A. S. H., Noda, J., Wacker, L., Volkamer, R., Fortner, E., Wang, J., Laskin, A., Shutthanandan, V., Zheng, J., Zhang, R., Paredes-Miranda, G., Arnott, W. P., Molina, L. T., Sosa, G., Querol, X., and Jimenez, J. L.: Mexico city aerosol analysis during MILAGRO using high resolution aerosol mass spectrometry at the urban supersite (T0) Part 2: Analysis of the biomass burning contribution and the non-fossil carbon fraction, Atmos. Chem. Phys., 10, 5315-5341, doi:10.5194/acp-10-5315-2010, 2010.

Allan, J. D., Williams, P. I., Morgan, W. T., Martin, C. L., Flynn, M. J., Lee, J., Nemitz, E., Phillips, G. J., Gallagher, M. W., and Coe, H.: Contributions from transport, solid fuel burning and cooking to primary organic aerosols in two UK cities, Atmos. Chem. Phys., 10, 647-668, doi:10.5194/acp-10-647-2010, 2010.

Amato, F., Pandolfi, M., Escrig, A., Querol, X., Alastuey, A., Pey, J., Perez, N., and Hopke, P. K.: Quantifying road dust resuspension in urban environment by Multilinear Engine: a comparison with PMF2, Atmos. Environ., 43, 2770-2780, 2009.

Andersson, A., Sheesley, R. J., Kruså, M., Johansson, C., and Gustafsson, Ö.: ${ }^{14} \mathrm{C}$-Based source assessment of soot aerosols in Stockholm and the Swedish EMEP-Aspvreten regional background site, Atmos. Environ., 45, 215-222, 2011.

Bae, M. S., Schauer, J. J., DeMinter, J. T., Turner, J. R., Smith, D., and Cary, R. A.: Validation of a semi-continuous instrument for elemental carbon and organic carbon using a thermal-optical method, Atmos. Environ., 38, 2885-2893, 2004.

Canagaratna, M. R., Jayne, J. T., Jimenez, J. L., Allan, J. D., Alfarra, M. R., Zhang, Q., Onasch, T. B., Drewnick, F., Coe, H., Middlebrook, A., Delia, A., Williams, L. R., Trimborn, A. M., Northway, M. J., DeCarlo, P. F., Kolb, C. E., Davidovits, P., and Worsnop, D. R.: Chemical and microphysical characterization of ambient aerosols with the Aerodyne Aerosol Mass Spectrometer, Mass Spectrom. Rev., 26, 185-222, 2007.

Cavalli, F., Viana, M., Yttri, K. E., Genberg, J., and Putaud, J.P.: Toward a standardised thermal-optical protocol for measuring atmospheric organic and elemental carbon: the EUSAAR protocol, Atmos. Meas. Tech., 3, 79-89, doi:10.5194/amt-3-79-2010, 2010.

Chirico, R., DeCarlo, P. F., Heringa, M. F., Tritscher, T., Richter, R., Prévôt, A. S. H., Dommen, J., Weingartner, E., Wehrle, G., Gysel, M., Laborde, M., and Baltensperger, U.: Impact of 
aftertreatment devices on primary emissions and secondary organic aerosol formation potential from in-use diesel vehicles: results from smog chamber experiments, Atmos. Chem. Phys., 10, 11545-11563, doi:10.5194/acp-10-11545-2010, 2010.

Chow, J. C., Watson, J. G., Lowenthal, D. H., Chen, L. W. A., and Motallebi, N.: Black and organic carbon emission inventories: Review and application to California, J. Air Waste Manage., 60, 497-507, 2010.

Cubison, M. J., Ortega, A. M., Hayes, P. L., Farmer, D. K., Day, D., Lechner, M. J., Brune, W. H., Apel, E., Diskin, G. S., Fisher, J. A., Fuelberg, H. E., Hecobian, A., Knapp, D. J., Mikoviny, T., Riemer, D., Sachse, G. W., Sessions, W., Weber, R. J., Weinheimer, A. J., Wisthaler, A., and Jimenez, J. L.: Effects of aging on organic aerosol from open biomass burning smoke in aircraft and lab studies, Atmos. Chem. Phys. Discuss., 11, 12103-12140, doi:10.5194/acpd-11-12103-2011, 2011.

Currie, L. A.: Evolution and multidisciplinary frontiers of ${ }^{14} \mathrm{C}$ aerosol science, Radiocarbon, 42, 115-126, 2000.

DeCarlo, P. F., Kimmel, J. R., Trimborn, A., Northway, M. J., Jayne, J. T., Aiken, A. C., Gonin, M., Fuhrer, K., Horvath, T., Docherty, K. S., Worsnop, D. R., and Jimenez, J. L.: Field-deployable, High-Resolution, Time-of-Flight Aerosol Mass Spectrometer, Anal. Chem., 78, 8281-8289, 2006.

DeCarlo, P. F., Ulbrich, I. M., Crounse, J., de Foy, B., Dunlea, E. J., Aiken, A. C., Knapp, D., Weinheimer, A. J., Campos, T., Wennberg, P. O., and Jimenez, J. L.: Investigation of the sources and processing of organic aerosol over the Central Mexican Plateau from aircraft measurements during MILAGRO, Atmos. Chem. Phys., 10, 5257-5280, doi:10.5194/acp-10-52572010, 2010.

Dunlea, E. J., Herndon, S. C., Nelson, D. D., Volkamer, R. M., San Martini, F., Sheehy, P. M., Zahniser, M. S., Shorter, J. H., Wormhoudt, J. C., Lamb, B. K., Allwine, E. J., Gaffney, J. S., Marley, N. A., Grutter, M., Marquez, C., Blanco, S., Cardenas, B., Retama, A., Ramos Villegas, C. R., Kolb, C. E., Molina, L. T., and Molina, M. J.: Evaluation of nitrogen dioxide chemiluminescence monitors in a polluted urban environment, Atmos. Chem. Phys., 7, 2691-2704, doi:10.5194/acp-7-2691-2007, 2007.

Fine, P. M., Cass, G. R., and Simoneit, B. R. T.: Chemical characterization of fine particle emissions from the fireplace combustion of wood types grown in the Midwestern and Western United States, Environ. Eng. Sci., 21, 387-409, 2004.

Forster, P., Ramaswamy, V., Artaxo, P., Berntsen, T., Betts, R., Fahey, D. W., Haywood, J., Lean, J., Lowe, D. C., Myhre, G., Nganga, J., Prinn, R., Raga, G., Schulz, M., and Van Dorland, R.: Changes in Atmospheric Constituents and in Radiative Forcing, in: Climate Change 2007: The Physical Science Basis, Contribution of Working Group I to the Fourth Assessment Report of the Intergovernmental Panel on Climate Change, edited by: Solomon, S., Qin, D., Manning, M., Chen, Z., Marquis, M., Averyt, K. B., Tignor, M., Miller, H. L., Cambridge University Press, Cambridge, United Kingdom and New York, NY, USA, 2007.

Gelencsér, A., May, B., Simpson, D., Sánchez-Ochoa, A., Kasper-Giebl, A., Puxbaum, H., Caseiro, A., Pio, C., and Legrand, M.: Source apportionment of PM2.5 organic aerosol over Europe: Primary/secondary, natural/anthropogenic, and fossil/biogenic origin, J. Geophys. Res., 112, D23S04, doi:10.1029/2006JD008094, 2007.
Gerde, P., Muggenburg, B. A., and Dahl, A. R.: The rapid alveolar absorption of diesel soot-adsorbed benzo[a]pyrene: bioavalaibility, metabolism and dosimetry of an inhaled particle-borne carcinogen, Carcinogenesis, 22, 741-749, 2001.

Gilardoni, S., Vignati, E., Cavalli, F., Putaud, J. P., Larsen, B. R., Karl, M., Stenström, K., Genberg, J., Henne, S., and Dentener, F.: Better constraints on sources of carbonaceous aerosols using a combined ${ }^{14} \mathrm{C}$ - macro tracer analysis in a European rural background site, Atmos. Chem. Phys., 11, 5685-5700, doi:10.5194/acp-11-5685-2011, 2011.

Gonçalves, C., Alves, C., Evtyugina, M., Mirante, F., Pio, C., Caseiro, A., Schmidl, C., Bauer, H., and Carvalho, F.: Characterisation of PM10 emissions from woodstove combustion of common woods grown in Portugal, Atmos. Environ., 44, 4474-4480, 2010.

Grantz, D. A., Garner, J. H. B., and Johnson, D. W.: Ecological effects of particulate matter, Environ. Int., 29, 213-239, 2003.

Graus, M., Müller, M., and Hansel, A.: High Resolution PTR-TOF: Quantification and formula confirmation of VOC in real time, J. Am. Soc. Mass Spectrom., 21, 1037-1044, 2010.

Grieshop, A. P., Logue, J. M., Donahue, N. M., and Robinson, A. L.: Laboratory investigation of photochemical oxidation of organic aerosol from wood fires 1: measurement and simulation of organic aerosol evolution, Atmos. Chem. Phys., 9, 1263-1277, doi:10.5194/acp-9-1263-2009, 2009.

Gustafsson, Ö, Haghseta, F., Chan, C., MacFarlane, J., and Gschwend, P. M.: Quantification of the dilute sedimentary soot phase: implications for PAH speciation and bioavailability, Env. Sci. Technol., 31, 203-209, 1997.

Gustafsson, Ö, Bucheli, T. D., Kukulska, Z., Andersson, M., Largeu, C., Rouzaud, J. N., Reddy, C. M., and Eglinton, T. I.: Evaluation of a protocol for the quantification of black carbon in sediments, Glob. Biogeochem. Cycles, 15, 881-890, 2001.

Gustafsson, Ö., Kruså, M., Zencak, Z., Sheesley, R. J., Granat, L., Engström, E., Praveen, P. S., Rao, P. S. P., Leck, L., and Rodhe, H.: Brown clouds over South Asia: Biomass or fossil fuel combustion?, Science, 323, 495-498, 2009.

Handa, D., Nakajima, H., Arakaki, T., Kumata, H., Shibata, Y., and Uchida, M.: Radiocarbon analysis of BC and OC in PM10 aerosols at Cape Hedo, Okinawa, Japan, during long-range transport events from East Asian countries, Nucl. Instrum. Meth. B, 268, 1125-1128, 2010.

Hennigan, C. J., Sullivan, A. P., Collett Jr., J. L., and Robinson, A. L.: Levoglucosan stability in biomass burning particles exposed to hydroxyl radicals, Geophys. Res. Lett., 37, L09806, doi:10.1029/2010GL043088, 2010.

Hildemann, L. M., Markowski, G. R., and Cass, G. R.: Chemical composition of emissions from urban sources of fine organic aerosol, Environ. Sci. Technol., 25, 744-759, 1991.

Hildemann, L. M., Klinedinst, D. B., Klouda, G. A., Currle, L. A., and Cass G. R.: Sources of urban contemporary carbon aerosol, Environ. Sci. Technol., 28, 1565-1576, 1994.

Highwood, E. J. and Kinnersley, R. P.: When smoke gets in our eyes: The multiple impacts of atmospheric black carbon on climate, air quality and health, Environ. Int., 32, 560-566, 2006.

Hodzic, A., Jimenez, J. L., Prévôt, A. S. H., Szidat, S., Fast, J. D., and Madronich, S.: Can 3-D models explain the observed fractions of fossil and non-fossil carbon in and near Mexico City?, Atmos. Chem. Phys., 10, 10997-11016, doi:10.5194/acp- 
10-10997-2010, 2010.

Huang, X.-F., He, L.-Y., Hu, M., Canagaratna, M. R., Sun, Y., Zhang, Q., Zhu, T., Xue, L., Zeng, L.-W., Liu, X.-G., Zhang, Y.-H., Jayne, J. T., Ng, N. L., and Worsnop, D. R.: Highly time-resolved chemical characterization of atmospheric submicron particles during 2008 Beijing Olympic Games using an Aerodyne High-Resolution Aerosol Mass Spectrometer, Atmos. Chem. Phys., 10, 8933-8945, doi:10.5194/acp-10-8933-2010, 2010.

INE (Instituto Nacional de Estadistica, Spanish National Institute of Statistics), Censos de Población y Viviendas 2001, Resultados definitivos, 2001.

Jimenez, J. L., Canagaratna, M. R., Donahue, N. M., Prevot, A. S. H., Zhang, Q., Kroll, J. H., DeCarlo, P. F., Allan, J. D., Coe, H., Ng, N. L., Aiken, A. C., Docherty, K. S., Ulbrich, I. M., Grieshop, A. P., Robinson, A. L., Duplissy, J., Smith, J. D., Wilson, K. R., Lanz, V. A., Hueglin, C., Sun, Y. L., Tian, J., Laaksonen, A., Raatikainen, T., Rautiainen, J., Vaattovaara, P., Ehn, M., Kulmala, M., Tomlinson, J. M., Collins, D. R., Cubison, M. J., Dunlea, E. J., Huffman, J. A., Onasch, T. B., Alfarra, M. R., Williams, P., Bower, K., Kondo, Y., Schneider, J., Drewnick, F., Borrmann, S., Weimer, S., Demerjian, K., Salcedo, D., Cottrell, L., Griffin, R., Takami, A., Miyoshi, T., Hatakeyama, S., Shimono, A., Sun, J. Y., Zhang, Y. M., Dzepina, K., Kimmel, J. R., Sueper, D., Jayne, J. T., Herndon, S. C., Trimborn, A. M., Williams, L. R., Wood, E. C., Middlebrook, A. M. , Kolb, C. E., Baltensperger, U., and Worsnop, D. R.: Evolution of organic aerosols in the atmosphere, Science, 326, 1525-1529, 2009.

Jorba, O., Pandolfi, M., Spada, M., Baldasano, J. M., Pey, J., Alastuey, A., Arnold, D., Sicard, M., Artiñano, B., Revuelta, M. A., and Querol, X.: The DAURE field campaign: meteorological overview, Atmos. Chem. Phys. Discuss., 11, 4953-5001, doi:10.5194/acpd-11-4953-2011, 2011.

Krzyzanowski, M. and Cohen, A.: Update of WHO air quality guidelines, Air Qual. Atmos. Health, 1, 7-13, 2008.

Lanz, V. A., Alfarra, M. R., Baltensperger, U., Buchmann, B., Hueglin, C., and Prévôt, A. S. H.: Source apportionment of submicron organic aerosols at an urban site by factor analytical modelling of aerosol mass spectra, Atmos. Chem. Phys., 7, 1503-1522, doi:10.5194/acp-7-1503-2007, 2007.

Lavanchy, V. M. H., Gäggeler, H. W., Nyeki, S., and Baltensperger, U.: Elemental carbon (EC) and black carbon (BC) measurements with a thermal method and an aethalometer at the high-alpine research station Jungfraujoch, Atmos. Environ., 33, 2759-2769, 1999.

Lee, D. S. and Pacyna, J. M.: An industrial emissions inventory of calcium for Europe, Atmos. Environ., 33, 1687-1697, 1999.

Levin, I., Naegler, T., Kromer, B., Diehl, M., Francey, R. J., GomezPelaez, A. J., Steele, L. P., Wagenbach, D., Weller, R., and Worthy, D. E.: Observations and modelling of the global distribution and long-term trend of atmospheric ${ }^{14} \mathrm{CO}_{2}$, Tellus B, 62, 26-46, 2010.

Li, N., Sioutas, C., Cho, A., Schmitz, D., Misra, C., Sempf, J., Wang, M. Y., Oberley, T., Froines, J., and Nel, A.: Ultrafine particulate pollutants induce oxidative stress and mitocondrial damage, Environ. Health Perspec., 111, 455-460, 2003.

Lindinger, W., Hansel, A., and Jordan, A.: On-line monitoring of volatile organic compounds at pptv levels by means of protontransfer-reaction mass spectrometry (PTR-MS) - Medical appli- cations, food control and environmental research, Int. J. Mass Spectrom., 173, 191-241, 1998.

Martin, S. T., Andreae, M. O., Althausen, D., Artaxo, P., Baars, H., Borrmann, S., Chen, Q., Farmer, D. K., Guenther, A., Gunthe, S. S., Jimenez, J. L., Karl, T., Longo, K., Manzi, A., Müller, T., Pauliquevis, T., Petters, M. D., Prenni, A. J., Pöschl, U., Rizzo, L. V., Schneider, J., Smith, J. N., Swietlicki, E., Tota, J., Wang, J., Wiedensohler, A., and Zorn, S. R.: An overview of the Amazonian Aerosol Characterization Experiment 2008 (AMAZE-08), Atmos. Chem. Phys., 10, 11415-11438, doi:10.5194/acp-1011415-2010, 2010.

Matson, P., Lohse, K. A., and Hall, S. J.: The globalization of nitrogen deposition: Consequences for terrestrial ecosystems, Ambio, 31, 113-119, 2002.

Mauderly, J. L. and Chow, J. C.: Health effects of organic aerosols, Inhal. Toxicol., 20, 257-288, 2008.

Millán, M. M., Salvador, R., Mantilla, E., and Kallos, G.: Photooxidant dynamics in the Mediterranean basin in summer: Results from European research projects, J. Geophys. Res., 102, 88118823, doi:10.1029/96JD03610, 1997.

Mohn, J., Szidat, S., Fellner, J., Rechberger, H., Quartier, R., Buchmann, B., and Emmenegger, L.: Determination of biogenic and fossil $\mathrm{CO}_{2}$ emitted by waste incineration based on ${ }^{14} \mathrm{CO}_{2}$ and mass balances, Bioresource Technol., 99, 6471-6479, 2008.

Mohr, C., DeCarlo, P. F., Heringa, M. F., Chirico, R., Slowik, J. G., Richter, R., Reche, C., Alastuey, A., Querol, X., Seco, R., Peñuelas, J., Jiménez, J. L., Crippa, M., Zimmermann, R., Baltensperger, U., and Prévôt, A. S. H.: Identification and quantification of organic aerosol from cooking and other sources in Barcelona using aerosol mass spectrometer data, Atmos. Chem. Phys. Discuss., 11, 27383-27420, doi:10.5194/acpd-11-273832011, 2011.

Müller, M., Graus, M., Ruuskanen, T. M., Schnitzhofer, R., Bamberger, I., Kaser, L., Titzmann, T., Hörtnagl, L., Wohlfahrt, G., Karl, T., and Hansel, A.: First eddy covariance flux measurements by PTR-TOF, Atmos. Meas. Tech., 3, 387-395, doi:10.5194/amt-3-387-2010, 2010.

Murphy, D. M., Cziczo, D. J., Froyd, K. D., Hudson, P. K., Matthew, B. M., Middlebrook, A. M., Peltier, R. E., Sullivan, A., Thomson, D. S., and Weber, R. J.: Single particle mass spectrometry of tropospheric aerosol particles, J. Geophys. Res., 111, D23S32, doi:10.1029/2006JD007340, 2006.

Nel A.: Air pollution-related illness: Effects of particles, Science, 308, 804-806, 2005.

Oja, V. and Suuberg, E. M.: Vapor pressures and enthalpies of sublimation of D-glucose, D-xylose, cellobiose, and levoglucosan, J. Chem. Eng. Data, 44, 26-29, 1999.

Paatero, P.: The Multilinear Engine - a table-driven least squares program for solving multilinear problems, including the n-way parallel factor analysis model, J. Comput. Graph. Stat., 8, 854888, 1999.

Pandolfi, M., Cusack, M., Alastuey, A., and Querol, X.: Variability of aerosol optical properties in the Western Mediterranean Basin, Atmos. Chem. Phys., 11, 8189-8203, doi:10.5194/acp-11-81892011, 2011a.

Pandolfi, M., Querol, X., Alastuey, A., Jimenez, J., Jorba, O., Stohl, A., Comerón, A., Sicard, M., Pey, J, vanDrooge, B., and the DAURE team: Source and origin of PM in the Western Mediterranean Basin: An Overview of the DAURE campaign, in prepa- 
ration, Atmos. Chem. Phys. Discuss., in prep., 2011 b.

Pérez, N., Pey, J., Castillo, S., Viana, M., Alastuey, A., and Querol, $\mathrm{X}$.: Interpretation of the variability of levels of regional background aerosols in the Western Mediterranean, Sci. Total Environ., 407, 527-540, 2008a.

Pérez, N., Pey, J., Querol, X., Alastuey, A., López, J. M., and Viana, M.: Partitioning of major and trace components in PM10 PM2.5-PM1 at an urban site in Southern Europe, Atmos. Environ., 42, 1677-1691, 2008b.

Pérez, N., Pey, J., Cusack, M., Reche, C., Querol, X., Alastuey, A., and Viana, M.: Variability of particle number, black carbon and PM10, PM2.5 and PM1 levels and speciation: Influence of road traffic emissions on urban air quality, Aerosol Sci. Tech., 44, 487-499, 2010.

Perron, N.: Radiocarbon-supported source apportionment of carbonaceous aerosols, PhD Thesis, University of Bern, Bern, 2010.

Perron, N., Sandradewi, J., Alfarra, M. R., Lienemann, P., Gehrig, R., Kasper-Giebl, A., Lanz, V. A., Szidat, S., Ruff, M., Fahrni, S., Wacker, L., Baltensperger, U., and Prévôt, A. S. H.: Composition and sources of particulate matter in an industrialised Alpine valley, Atmos. Chem. Phys. Discuss., 10, 9391-9430, doi:10.5194/acpd-10-9391-2010, 2010.

Pey, J., Pérez, N., Castillo, S., Viana, M., Moreno, T., Pandolfi, M., López-Sebastián, J. M., Alastuey, A., and Querol., X.: Geochemistry of regional background aerosols in the Western Mediterranean, Atmos. Res., 94, 422-435, 2009.

Pey, J., Pérez, N., Querol, X., Alastuey, A., Cusack, M., and Reche, C.: Intense winter atmospheric pollution episodes affecting the Western Mediterranean, Sci. Total Environ., 408, 1951-1959, 2010.

Pope III, C. A. and Dockery, D. W.: Health effects of fine particulate air pollution: Lines that connect, J. Air Waste Manage., 56, 709742, 2006

Pöschl, U., Martin, S. T., Sinha, B., Chen, Q., Gunthe, S. S., Huffman, J. A., Borrmann, S., Farmer, D. K., Garland, R. M., Helas, G., Jimenez, J. L., King, S. M., Manzi, A., Mikhailov, E., Pauliquevis, T., Petters, M. D., Prenni, A. J., Roldin, P., Rose, D., Schneider, J., Su, H., Zorn, S. R., Artaxo, P., and Andreae, M. O.: Rainforest aerosols as biogenic nuclei of clouds and precipitation in the Amazon, Science, 329, 1513-1516, 2010.

Querol, X., Alastuey, A., Rodríguez, S., Plana, F., Mantilla, E., and Ruiz, C. R.: Monitoring of PM10 and PM2.5 ambient air levels around primary particulate anthropogenic emission sources, Atmos. Environ., 35, 848-858, 2001.

Reche, C., Querol, X., Alastuey, A., Viana, M., Pey, J., Moreno, T., Rodrguez, S., González, Y., Fernández-Camacho, R., de la Rosa, J., Dall'Osto, M., Prévôt, A. S. H., Hueglin, C., Harrison, R. M., and Quincey, P.: New considerations for PM, black carbon and particle number concentration for air quality monitoring across different European cities, Atmos. Chem. Phys., 11, 6207-6227, doi:10.5194/acp-11-6207-2011, 2011.

Robinson, A. L., Donahue, N. M., Shrivastava, M. K., Weitkamp, E. A., Sage, A. M., Grieshop, A. P., Lane, T. E., Pierce, J. R., and Pandis, S. N.: Rethinking organic aerosols: Semivolatile emissions and photochemical aging, Science, 315, 1259-1262, 2007.

Ruff, M., Wacker, L., Gäggeler, H. W., Suter, M., Synal, H. A., and Szidat, S.: A gas ion source for radiocarbon measurements at 200 kV, Radiocarbon, 49, 307-314, 2007.

Ruff, M., Szidat, S., Gäggeler, H. W., Suter, M., Synal, H. A., and
Wacker, L.: Gaseous radiocarbon measurements of small samples, Nucl. Instrum. Meth. B, 268, 790-794, 2010.

Saarnio, K., Aurela, M., Timonen, H., Saarikoski, S., Teinilä, K., Mäkelä, T., Sofiev, M., Koskinen, J., Aalto, P. P., Kulmala, M., Kukkonen, J., and Hillamo, R.: Chemical composition of fine particles in fresh smoke plumes from boreal wild-land fires in Europe, Sci. Total Environ., 408, 2527-2542, 2010.

Schauer, J. J., Rogge, W. F., Hildemann, L. M., Mazurek, M. A., and Cass, G. R.: Source apportionment of airborne particulate matter using organic compounds as tracers, Atmos. Environ., 30, 3837-3855, 1996.

Schauer, J. J., Kleeman, M. J., Cass, G. R., and Simoneit, B. R. T.: Measurement of emissions from air pollution sources, 1. C-1 through C-29 organic compounds from meat charbroiling, Environ. Sci. Technol., 33, 1566-1577, 1999.

Schmidl, C., Marr, I. L., Caseiro, A., Kotianová, P., Berner, A., Bauer, H., Kasper-Giebl, A., and Puxbaum, H.: Chemical characterisation of fine particle emissions from wood stove combustion of common woods growing in mid-European Alpine regions, Atmos. Environ., 42, 126-141, 2008.

Seco, R., Peñuelas, J., Filella, I., Llusià, J., Molowny-Horas, R., Schallhart, S., Metzger, A., Müller, M., and Hansel, A.: Contrasting winter and summer VOC mixing ratios at a forest site in the Western Mediterranean Basin: the effect of local biogenic emissions, Atmos. Chem. Phys. Discuss., 11, 20389-20431, doi:10.5194/acpd-11-20389-2011, 2011.

Sillanpää, M., Frey, A., Hillamo, R., Pennanen, A. S., and Salonen, R. O.: Organic, elemental and inorganic carbon in particulate matter of six urban environments in Europe, Atmos. Chem. Phys., 5, 2869-2879, doi:10.5194/acp-5-2869-2005, 2005.

Simoneit, B. R. T., Schauer, J. J., Nolte, C. G., Oros, D. R., Elias, V. O., Fraser, M. P., Rogge, W. F., and Cass, G. R.: Levoglucosan, a tracer for cellulose in biomass burning and atmospheric particles, Atmos. Environ., 33, 173-182, 1999.

Steinbacher, M., Zellweger, C., Schwarzenbach, B., Bugmann, S., Buchmann, S., Ordóñez, C., Prevot, A. S. H., and Hueglin, C.: Nitrogen oxide measurements at rural sites in Switzerland: Bias of conventional measurement techniques, J. Geophys. Res., 112, D11307, doi:10.1029/2006JD007971, 2007.

Stuiver, M. and Polach, H. A.: Reporting of ${ }^{14} \mathrm{C}$ Data - Discussion, Radiocarbon, 19, 355-363, 1977.

Sullivan, A. P., Holden, A. S., Patterson, L. A., McMeeking, G. R., Kreidenweis, S. M., Malm, W. C., Hao, W. M., Wold, C. E., and Collett, J. L.: A method for smoke marker measurements and its potential application for determining the contribution of biomass burning from wildfires and prescribed fires to ambient PM2.5 organic carbon, J. Geophys. Res.-Atmos., 113, D22302, doi:10.1029/2008JD010216, 2008.

Sun, Y.-L., Zhang, Q., Schwab, J. J., Demerjian, K. L., Chen, W.N., Bae, M.-S., Hung, H.-M., Hogrefe, O., Frank, B., Rattigan, O. V., and Lin, Y.-C.: Characterization of the sources and processes of organic and inorganic aerosols in New York city with a high-resolution time-of-flight aerosol mass apectrometer, Atmos. Chem. Phys., 11, 1581-1602, doi:10.5194/acp-11-15812011, 2011.

Szidat, S.: Sources of Asian haze, Science, 323, 470-71, 2009.

Szidat, S., Jenk, T. M., Gäggeler, H. W., Synal, H.-A., Fisseha, R., Baltensperger, U., Kalberer, M., Samburova, V., Wacker, L., Saurer, M., Schwikowski, M., and Hajdas, I.: Source apportion- 
ment of aerosols by ${ }^{14} \mathrm{C}$ measurements in different carbonaceous particle fractions, Radiocarbon 46, 475-484, 2004a.

Szidat, S., Jenk, T. M., Gäggeler, H. W., Synal, H.-A., Hajdas, I., Bonani, G., Saurer, M.: THEODORE, a two-step heating system for the $\mathrm{EC} / \mathrm{OC}$ determination of radiocarbon $\left({ }^{14} \mathrm{C}\right)$ in the environment, Nucl. Instrum. Meth. B, 223/224, 829-836, 2004b.

Szidat, S., Jenk, T. M., Synal, H.-A., Kalberer, M., Wacker, L., Hajdas, I., Kasper-Giebl, A., and Baltensperger, U.: Contributions of fossil fuel, biomass-burning, and biogenic emissions to carbonaceous aerosols in Zurich as traced by ${ }^{14} \mathrm{C}$, J. Geophys. Res., 111, D07206, doi:10.1029/2005JD006590, 2006.

Szidat, S., Prevot, A. S. H., Sandradewi, J., Alfarra, M. R., Synal, H. A., Wacker, L., and Baltensperger, U.: Dominant impact of residential wood burning on particulate matter in Alpine valleys during winter, Geophys. Res. Lett., 34, L05820, doi:10.1029/2006GL028325, 2007.

Szidat, S., Ruff, M., Perron, N., Wacker, L., Synal, H.-A., Hallquist, M., Shannigrahi, A. S., Yttri, K. E., Dye, C., and Simpson, D.: Fossil and non-fossil sources of organic carbon (OC) and elemental carbon (EC) in Göteborg, Sweden, Atmos. Chem. Phys., 9, 1521-1535, doi:10.5194/acp-9-1521-2009, 2009.

Tagliavini, E., Moretti, F., Decesari, S., Facchini, M. C., Fuzzi, S., and Maenhaut, W.: Functional group analysis by $\mathrm{H}$ $\mathrm{NMR} /$ chemical derivatization for the characterization of organic aerosol from the SMOCC field campaign, Atmos. Chem. Phys., 6, 1003-1019, doi:10.5194/acp-6-1003-2006, 2006.
Ulbrich, I. M., Canagaratna, M. R., Zhang, Q., Worsnop, D. R., and Jimenez, J. L.: Interpretation of organic components from Positive Matrix Factorization of aerosol mass spectrometric data, Atmos. Chem. Phys., 9, 2891-2918, doi:10.5194/acp-9-2891-2009, 2009.

Watson, J.: Visibility: Science and regulation, J. Air Waste Manage., 52, 628-713, 2002.

Zencak, Z., Elmquist, M., and Gustafsson, O.: Quantification and radiocarbon source apportionment of black carbon in atmospheric aerosols using the CTO-375 method, Atmos. Environ., 41, 7895-7906, 2007.

Zhang, X., Hecobian, A., Zheng, M., Frank, N. H., and Weber, R. J.: Biomass burning impact on PM 2.5 over the southeastern US during 2007: integrating chemically speciated FRM filter measurements, MODIS fire counts and PMF analysis, Atmos. Chem Phys., 10, 6839-6853, doi:10.5194/acp-10-6839-2010, 2010.

Zheng, M., Cass, G. R., Ke, L., Wang, F., Schauer, J. J., Edgerton, E. S., and Russell, A. G.: Source apportionment of daily fine particulate matter at Jefferson street, Atlanta, GA, during summer and winter, J. Air Waste Manag. Assoc., 57, 228-242, 2007. 